\title{
The Causes of Inner-City Poverty: Eight Hypotheses in Search of Reality
}

Michael B. Teitz

Public Policy Institute of California and

University of California, Berkeley

Karen Chapple

University of California, Berkeley

\begin{abstract}
Over the past 40 years, poverty among the inhabitants of U.S. inner cities has remained stubbornly resistant to public policy prescriptions. Especially for African Americans and Latinos, the gap between their economic well-being and that of the mainstream has widened despite persistent and repeated efforts to address the problem. At the same time, a continuing stream of research has sought to explain urban poverty, with a wide variety of explanations put forward as the basis for policy. This paper reviews that research, organizing it according to eight major explanations or hypotheses: structural shifts in the economy, inadequate human capital, racial and gender discrimination, adverse cultural and behavioral factors, racial and income segregation, impacts of migration, lack of endogenous growth, and adverse consequences of public policy. We conclude that all of the explanations may be relevant to urban poverty but that their significance and the degree to which they are well supported varies substantially.
\end{abstract}

It is now more than 12 years since the publication of William J. Wilson and Robert Aponte's (1985) survey of urban poverty in the United States. That report still stands alone as an effort to produce "a state of the art review of research and theoretical writing on urban poverty" (Wilson and Aponte, 1985). However, in the intervening years, there has been much work on and even more debate about the nature and causes of poverty in U.S. inner cities. Much of the contribution, indeed, may be attributed to Wilson, who has sparked a new round of work in the field. At the same time, there has been a wave of interest in reform that is intended to respond to the seemingly intractable nature of urban poverty. This article surveys both the research on and the controversies over its validity and its policy implications. It is not comprehensive, but it does attempt to make sense of an enormous body of ideas and research that bear on the topic of inner-city poverty. It seeks to clarify the principal themes of urban poverty that seem to us to be part of current intellectual discourse. We do this by suggesting hypotheses about inner-city poverty that are part of the debates about its causes and what should be done. 
Since President Lyndon Johnson's declaration of War on Poverty and the passage of the Economic Opportunity Act of 1964, optimism that had surrounded those measures has faded. The economic, fiscal, and social conditions of the old central cities have declined, while their inner-ghetto areas have become zones of calamity. Their residents are not only living in poverty, but they must also contend with levels of drug use and violence that, although currently in decline, would have seemed inconceivable in the early 1960s. Even though the march of urban decline was evident then in abandonment and crime, there was optimism that the vast productivity of the U.S. economy, together with the social advances of the civil rights movement, could bring about positive fundamental change in the lives of the urban poor. Not much was known about how to institute change, what the obstacles were, or what it would cost, but progress did seem possible (Wilson and Aponte, 1985).

In 1997, both the underlying confidence and optimism are hard to sustain. The War on Poverty and its successor programs seem to have made little impact on those populations that are at the lowest economic levels in U.S. society. If anything, the widening income distribution and the curbing of governmental expenditures for these groups have left them worse off. Yet one result of the efforts to address poverty in the intervening years has been the growth of well-articulated theoretical notions coupled with serious efforts to ground these ideas in empirical analysis. Much of the work does not specifically speak to urban poverty or the conditions of life in the ghettos of the major cities, which is partly due to the origins of policy research in national debates about issues such as welfare, health, and education. Economists have used large, newly available data sets, including longitudinal data on individuals and families, along with new analytical tools to draw conclusions about behavior in the aggregate. Even so, the plight of the cities has driven a considerable amount of research that is rigorous and quantitative, as well as a resurgence of qualitative and phenomenological research that seeks to understand the complex fabric of life for the urban poor.

Concurrently, shifting political attitudes and disillusionment with the policies that have been tried are giving rise to a new surge of debate and reform. Most visible in the 1990s is the effort to reform the welfare system to increase work incentives and to limit its use as a long-term source of support for able-bodied adults, even when they have small children. Behind this policy change has been a decade-long ideological debate about the nature and causes of poverty, pitting conservatives against liberals. This article does not describe that debate, except where directly necessary. Rather, we concentrate on research about poverty and its relation to the conditions of inner cities and their inhabitants. Nonetheless, the research must be seen in the context of a noisier and sometimes ill-informed public discourse. Over the long term, research that accurately reveals reality tends to prevail-witness the debate over cigarette smoking. That same debate shows how long the process can take and how stubbornly those with interests in a particular view can maintain their position. The issue of inner-city poverty is more complex and more difficult to resolve than even the most complicated single-issue debate. Understanding poverty is correspondingly more difficult, yet its comprehension is vital to the national interest.

To grasp urban poverty in the United States, one must know the inner cities. In the 1990s, their conditions are decidedly mixed (Glickman et al., 1996). Some are prospering; the long-term population decline of others appears to be slowing and new growth sectors are emerging; for still others, conditions are worse than ever. The 1980s saw continuing population decline of as much as 10 to 15 percent in many older cities in the Midwest, Northeast, and South, even as their metropolitan areas grew, while newer central cities in the West and Southwest were still gaining population. A look at the 10 largest central 
cities in 1990 reveals that 6 of them were in the South or West-Dallas, Houston, Los Angeles, Phoenix, San Antonio, and San Diego. These cities grew in population by more than 10 percent from 1980 to 1990, except for Houston, which grew by slightly more than 2 percent. Of the remaining four cities-Chicago, Detroit, New York City, and Philadelphia-all declined, except for New York City, which grew by more than 3 percent. Other traditionally notable central cities, such as Boston, Cleveland, Pittsburgh, and St. Louis, were no longer even among the 20 largest cities in the United States, having been replaced by such fast-growing places as Jacksonville, Memphis, and San Jose. The most precipitous population declines of the decade occurred mostly among older, smaller central cities, such as Newark, Pittsburgh, and St. Louis. Detroit was the only city among the 20 largest to decline by more than 10 percent. Clearly, when we speak of U.S. central or inner cities, we must now distinguish carefully between those newer cities that are still able to annex land or attract population and those cities that are either declining or in a condition of stability or slow growth. These latter cities are our primary focus in this article. The 1990 census revealed that their poverty rates were generally more than double those of their surrounding suburbs. For African-American and Hispanic populations, poverty rates were above 25 percent, and typically four to five times the suburban rates. Within the core ghetto areas, the figures were much higher still (Gibson, 1996).

Research on poverty in the United States tends to look at the large picture, using national databases to provide information for Federal policymakers. As a result, its conclusions generally argue that the poor are not much different from the rest of the population. They have less money, but their poverty status will usually not be permanent as their life circumstances change ( Sawhill, 1988; Levy and Murnane, 1992). While these statements may be true as a broad generalization, the experience of the inner cities suggests that the story in the ghettos is very different. Their inhabitants find it much harder to move out of poverty, their incomes are lower, and they are much more often detached from the labor market than other populations. This article focuses on that ghetto population. It may be only a small proportion of the total urban population, but it constitutes the key test of whether U.S. urban poverty can be addressed successfully.

This article seeks to describe what we know about urban poverty by framing eight hypotheses about its causes. In the next section, we set out the framework and the hypotheses in brief. The succeeding sections deal with each hypothesis in turn, giving its argument in the light of what we take to be the main findings of the research literature. The final section reflects on what is known, what is not known, and implications for policy.

\section{Hypotheses on Urban Poverty}

Whatever the debate about its nature and causes, almost all observers would agree that inner-city poverty is multidimensional, extraordinarily complex, and difficult to understand. Various disciplines and policy frameworks give rise to very different notions of poverty and of its sources. To economists, it is an issue of labor markets, productivity, incentives, human capital, and choice. Sociologists and anthropologists tend to emphasize social status and relations, behavior, and culture. For social psychologists, the issues may include self-image, group membership, and attitudes. For political scientists, the questions may focus on group power and access to collective resources. City planners and urbanists see the effects of urban structure, isolation, and transportation access. No single conceptual framework can incorporate or reconcile these conflicting and complementary perceptions, but, equally, a characterization that simply lists each disciplinary perspective would not do justice to the wealth of existing, cross-disciplinary insights. 
We have chosen to synthesize these insights through a set of eight hypotheses that seems to capture the main elements of the diverse views of urban poverty. The hypotheses are driven by four underlying themes of urban poverty that occur repeatedly across the multiple literatures on the subject of poverty. These themes are economic structure, population characteristics, societal institutions, and location. ${ }^{1}$ Although the themes are reflected in our hypotheses, they do not fit neatly into the broad categories. Rather we see them as reflecting the ways in which research on urban poverty has developed, often drawing from multiple sources. Thus they offer a useful way to encapsulate completed research. They should be seen not as classically testable assertions about the empirical world but rather as partial explanations that embody particular views and disciplinary perspectives on poverty. They serve as a structure for the organization of thought and as windows into the phenomenon of urban poverty. They also partially integrate the varying disciplinary views through the debates that are embodied by them. We make no claim that they cover all explanations of urban poverty, but they do seem to incorporate the most significant arguments.

Since the issue of urban poverty cuts at the heart of social policy in the United States, it is not surprising that ideology plays a substantial role in many of the debates about it. The hypotheses often reflect ideological, as well as empirical, social science debates. This is unavoidable. Nonetheless, the focal point of this article is not on ideology but rather on what may reasonably be claimed to be known about inner-city poverty. Ideology may well be critical to the decision about what to believe and what policies are to be preferred. We recognize that it subtly affects perceptions of empirical reality, particularly through its impact on what we choose to look at. Nonetheless, we have tried to avoid adopting any single ideological point of view. In social policy, what is "fact" is always debatable, but that does not mean that the search for a well-grounded basis for decision should be abandoned.

In brief, the eight hypotheses on inner-city poverty are:

- Inner-city poverty is the result of profound structural economic shifts that have eroded the competitive position of the central cities in the industrial sectors that historically provided employment for the working poor, especially minorities. Thus demand for their labor has declined disastrously.

- Inner-city poverty is a reflection of the inadequate human capital of the labor force, which results in lower productivity and inability to compete for employment in emerging sectors that pay adequate wages.

- Inner-city poverty results from the persistence of racial and gender discrimination in employment, which prevents the population from achieving its full potential in the labor market.

- Inner-city poverty is the product of the complex interaction of culture and behavior, which has produced a population that is isolated, self-referential, and detached from the formal economy and labor market.

- Inner-city poverty is the outcome of a long, historical process of segregating poor and minority populations in U.S. cities that resulted in a spatial mismatch between workers and jobs when employment decentralized.

- Inner-city poverty results from migration processes that simultaneously remove the middle-class and successful members of the community, thereby reducing social capital, while bringing in new, poorer populations whose competition in the labor market drives down wages and employment chances of residents. 
- Inner-city poverty reflects an endogenous growth deficit that results from low levels of entrepreneurship and access to capital, especially among minority populations.

- Inner-city poverty is the unanticipated consequence of public policy that was intended to alleviate social problems but has, in fact, caused them to worsen in some respects.

Each idea has advocates and opponents. The following sections present the principal arguments and literature for each one.

\section{Industrial Transformation: The Demand for Inner-City Workers}

This first hypothesis on urban poverty is actually part of a much larger debate about the changing nature of the U.S. economy in the late 20th century. In summary, it asserts that inner-city urban poverty is a product of the loss of employment opportunities that resulted from profound structural changes in the larger economy (Kasarda, 1985; Wilson, W.J., 1996, 1987). The key elements of that change are threefold:

- Transformation in the technology and organization of manufacturing.

- The relative growth of the service sector.

- The increasing role of international competition.

Until the 1970s, the post-World War II structure of production was remarkably favorable to labor. The social bargain between labor and capital that emerged after 1945 rested on oligopolization of key dynamic manufacturing sectors in the economy-such as automobiles, steel, electrical equipment, chemicals, and heavy machinery. These highproductivity sectors were characterized by relatively few, large firms and were heavily unionized. Productivity gains were occurring because of technological advances and substantial investment, and these gains were bargained into relatively high and increasing wages, the cost of which could be passed on through oligopolistic price setting by the firms. As a result, manual workers were able to enjoy rising standards of living with stable employment, interrupted only by periods of layoff during cyclical downturns.

This golden age of the industrial workers in the United States is partly mythological, but it had roots in reality (Webber and Rigby, 1996). Rising living standards, predictable employment at a family wage, and homeownership were no myth for millions of workers. Its effects even spilled onto members of minority groups, particularly African Americans, who continued to be socially marginalized, but who migrated from rural areas to cities and found work in factories. Demand for labor, as well as rising wages and productivity in the manufacturing sectors, also pushed demand and wages up in the less-productive service sectors. Although workers in these sectors had to deal with harsher working conditions, lower wages, and employment instability, they also experienced significant gains. As always, the key source of income growth was rising productivity, which was made possible in large part by the technological advances that had occurred but were not fully realized during the Depression and World War II. Other factors were also significant. Large-scale mass production, relatively few competitors, and a legal environment resulting from the Depression all supported unionization and pattern bargaining. Furthermore, the spreading effects of wage growth were also reinforced by restrictions on immigration and the relatively small birth cohorts of the Depression years entering the labor force, which meant that the work force could not expand rapidly. 
Most observers of the economy now accept that a major shift occurred during the 1970s. The rapid productivity growth of the postwar years came to an end-for reasons that are still being debated among economists and historians. Wage growth lagged, and the economy suffered multiple shocks from energy prices and rapid inflation. The surge of births in the postwar baby boom meant that the labor force grew rapidly, while women were entering the labor force in numbers unprecedented in peacetime. For workers in the inner cities, these phenomena were reinforced by powerful technological and competitive forces. Beginning in the 1960s, total manufacturing employment in older cities, such as New York and Philadelphia, had begun to fall, but this decline accelerated in the 1970s. Initially, the process was driven primarily by technological and market changes that rendered inner-city locations for manufacturing less profitable (Vernon, 1960). Evolving mass-production technology favored single-story plants on extensive sites to permit efficient handling, and the development of the suburbs and freeways provided the labor force, transportation, and communications that facilitated the transformation.

By the 1980s, however, manufacturing losses in both new and old plants were being exacerbated by foreign competition. As the United States embraced free trade, the aggregate effect was beneficial, but in some sectors and regions adverse impacts were undeniable, especially in older cities. The rise of new competitors—notably from Japan-opened the way to globalization of consumer goods production, both durable and nondurable, that was cheaper and frequently better. In many sectors, domestic production as a percentage of sales fell sharply and in some cases, such as television manufacturing, dropped effectively to zero. Perhaps as important, whole new product lines, including consumer electronics such as the videocassette recorder, never gained a production foothold in the United States. Plant closures and employment losses left the populations of the cities facing a future in which the hitherto cyclical fluctuations had turned into permanent job losses (Bluestone and Harrison, 1982). In key sectors, such as steel, automobiles, consumer electrical goods, textiles, and machinery, factories were vacant and decaying. Large cities, such as New York and Philadelphia, and smaller ones, such as Camden and Newark, New Jersey, alike were in trouble. Population groups, especially minorities, which were segregated in location and had quite recently been able to gain jobs paying decent wages, were now cut off from employment. Those remaining manufacturing and construction jobs were subject to intense competition in the labor market, even as they were being eliminated by technology. The social bargain between labor and capital disappeared, and unionization declined dramatically_along with growth in real wages. There emerged in society at large, but especially in cities, growing inequality in income distribution, combined with very high levels of unemployment, welfare dependency, and labor market detachment among the very poor.

Structural changes had happened previously in U.S. history without such radical effects on cities, though they had certainly devastated some groups of workers. For example, the carriage industry in Michigan was totally replaced by automobile manufacturing, but there was little to offset the loss of automobile production in Flint. What, in fact, might replace the lost sectors and employment in these cases? Two answers suggested themselves: services and high technology.

Throughout the second half of this century, employment in the service sectors has been growing faster than in manufacturing. This seemingly inexorable phenomenon was expected to generate new growth sufficient to maintain inner-city employment. Indeed, the locational advantages of the cities, their concentrations of business and consumer services, and the perceived need for face-to-face communication in services gave rise in the 1970s and early 1980s to a burst of theorizing and speculation about a new economic base for urban areas in the service society (Bell, 1973; Daniels, 1975; Stanback 
et al., 1981; Noyelle and Stanback, 1983). The flaw in the argument lay in the issue of productivity. The very fact of employment growth in services in comparison with manufacturing reflected the lower productivity of workers in these sectors (Cohen and Zysman, 1987). They were bipolar in wage and occupational structure-with growth in jobs with very high and very low wages and skills, but a decline in jobs with moderate wages and skills (Sassen-Koob, 1984; Harrison and Bluestone, 1988; Mollenkopf and Castells, 1991; Carnoy, 1994). There was little evidence that they could absorb manual workers of moderate skill at anywhere near the wage levels of manufacturing.

As the 1980s gave way to the 1990s, globalization and the information revolution reshaped financial services on an international scale (Castells, 1989; Sassen, 1991). The prospect of a service-based economy for key financial centers seemed likely, as London, New York, and Tokyo dominated world financial markets. But the hierarchy of such centers was not deep, and the ability of the sectors to sustain large-scale employment was challenged by the other perceived savior-high technology.

The high-technology answer seemed to lie in the creation of new manufacturing sectors, which - by virtue of high growth and rising productivity - might restore the promise of high-wage, stable employment. Such sectors were emerging in Silicon Valley and other centers that increasingly looked to a combination of electronics and information as their stock in trade. But also taking place were profound changes in the nature of manufacturing; these changes would be fatal to the cities' hopes for new sectors. Some of the most remarkable developments in the structure of manufacturing over the past two centuries occurred in the past two decades. The obvious ones are technological-the creation of entirely new industries based on the astonishing increase in information-processing power that resulted from the development of the silicon chip and the computer. The growth in the production of hardware and software for these sectors has been phenomenal, certainly equaling or exceeding anything in the Industrial Revolution. These industries have located to new sites, either in the suburbs in existing metropolitan areas or in rapidly growing, relatively new cities (Scott, 1993; Castells and Hall, 1994). Almost nowhere have they been significant as employment generators for older, inner cities. As growth generators, they are, at best, indirect. However, some elements in the new sectors hold promise for the cities; the production of new forms of information-based media is especially promising. To the extent that they are enhanced by a large number of creative people who seek out and enjoy urban environments, such sectors may well thrive in cities. Whether they yield much for the population in poverty is another issue. ${ }^{2}$

Important as increases in the high-technology sectors were in their own right, their impact on the structure of production may have been even greater. The past two decades have seen major changes both in the organization of production and in the perception of that organization. A simple version sees a transformation from large-scale, vertically integrated, mass production of standardized goods for oligopolized markets to networks of quasi-independent producers that can form and re-form into flexible combinations to produce continuously shifting products that respond to demands in highly competitive markets (Piore and Sabel, 1984; Saxenian, 1994; Harrison, 1994; Castells, 1996). Of course, both forms existed previously, and both continue to exist. Nonetheless, the perception that hierarchies of production and control have increasingly been displaced by networks is a very powerful one. From the instantaneous movement of capital across integrated financial networks, to the provision of just-in-time automobile manufacturing, to worldwide designers who respond to changing trends in clothing, the sense that the old structures and verities of production are no longer reliable seems unavoidable. At the heart of the process is the revolutionary shift in communications, information processing, and real-time control that is afforded by the new technologies. The full implications of 
these changes cannot yet be seen, but they are pervasive. By permitting producers to take full advantage of geographic differences in labor costs, yet maintain quality control without necessarily assuming ownership, the structure pushes competition to a new level of intensity.

But what does this trend in competition do for the cities? The answer is certainly not definitive, but in its emerging outlines, it is disturbing yet also offers hope. To the extent that this tendency makes cheap labor locations around the world more accessible, it further amplifies the competitive disadvantage of urban locations in the United States. The impact of increases in trade with low-wage countries on U.S. employment, especially on low-skilled workers, has been hotly debated (Freeman, 1995; Wood, 1995). Although there are exceptions, such as Adrian Wood's viewpoint, most economists see the overall impact as moderate, noting that only a modest proportion of workers are now in manufacturing and that declines in wages for low-skill workers have occurred simultaneously in sectors less affected by competition (Freeman, 1995). This situation does not seem to take into account the concentration of poor and minority workers in those sectors that have been decimated in the central cities during the past three decades. At the same time, the process of globalization may also reinforce the power of existing centers to sustain key design and control functions. This scenario reinforces the "world city" image, at least for some places, but it also suggests that the income gap between rich and poor will continue to widen, and it does little for those at the bottom of the income distribution (Sassen, 1991).

And what effect do these industrial shifts have on the employability of city residents? The transformation has favored a more educated labor force over blue-collar or entrylevel workers, and it has been most pronounced in the Northeast and Midwest, which house the greatest concentration of minority groups (Moss and Tilly, 1991; Kasarda, $1985,1989,1990)$. Moreover, the changes in the organization of production-in particular, the advent of flexible work arrangements, the diminishing role of the internal labor market, the declining rate of unionization, and the growth of new ethnic small business enclaves - seem to have particular disadvantages for African-American males (Moss and Tilly, 1991).

How shall we assess the structural change hypothesis as the basis for inner-city urban poverty? It certainly seems plausible. One has only to walk the former industrial district of any large, older city, from New York to San Francisco, to see its physical manifestations. Yet some nagging problems remain. Although many working people may be suffering under the new regime, why are some groups so much more affected than others? Why are some cities relatively worse off than others? Why does the market not see opportunities in the tragic waste of human resources that is mass unemployment? Why has society not taken effective measures to respond to this structural change as it has in other times and places? These problems and others suggest that, although we are undoubtedly in the grip of global change, national and local circumstances, such as labor supply, social structure, and urban structure, mediate its impacts.

\section{Human Capital Deficit:The Inner-City Labor Supply}

If there is any argument about income on which most economists would agree, it is that income growth in a given economy depends on growth in productivity of its workersthat is, on change in the level of real output per worker. The determinants of productivity and the way in which its fruits are distributed among workers, the owners of capital, the recipients of economic rent, and the public sector are the subjects of debates that have 
spanned the history of economic theory, but the core notion that productivity defines the limits of income is fundamental. If we look, then, at the incomes of inner-city residents and workers and find that they are so low as to place those residents in poverty, it is reasonable to ask whether productivity itself is a primary cause.

Productivity of workers is generally understood to be the outcome of many factors, but two among them are critical: physical and human capital (Becker, 1975). It is evident that a worker able to operate with more advanced equipment is likely to produce more than one who is not. What has come to be understood in the past two decades is that the factors that enable a worker to produce effectively in the first place are equally important. This notion of human capital - that is, the level of capability embedded in the individual worker-sees productivity as resulting from education and training, from skills developed through experience, and from understanding that comes with age-all interacting with what might be called innate potential. Enormous amounts of energy and intelligence have been focused on the questions of how human capital is acquired and the effects of its acquisition on productivity and income.

For inner-city poverty, the key questions raised by the human capital view of productivity concern (1) the extent to which inner-city populations are disadvantaged in the labor market because of a human capital deficit and (2) the role of that deficit (as opposed to other factors, such as discrimination) in maintaining poverty, which prevents people from realizing the income levels of a labor market that is indifferent to race. The first question will be taken up here. The second is the topic of the next section.

The literature on poverty and income inequality in the United States generally does not address these issues from a place-based perspective. Rather, economists studying poverty tend to work from large data sets that mingle urban and rural populations without distinguishing between growing and declining regions. Even where inner cities are singled out, there is only limited analysis of their populations that are especially disadvantaged. Nonetheless, there is little doubt that, for critical inner-city populations, a human capital deficit does indeed exist. It has been recognized and addressed at least since the War on Poverty in the 1960s and efforts began to improve educational opportunities and provide employment training.

Human capital may be expressed in three elements-education, job skills, and work experience - in addition to an individual's innate ability. For the most part, these elements are defined as the level of educational attainment (less than high school, high school diploma, and various levels of college), occupation and work history as indicators of skills, and age or years in the labor market, which serves as a proxy both for skills and experience. Thus, other things being equal, younger, less-educated populations would be expected to find employment in low-skill occupations and to receive lower wages and incomes.

To the extent that these elements are measurable, inner cities demonstrate significantly lower levels on all fronts. Their populations are younger, exhibit substantially lower levels of educational attainment, have less work experience, and find work in lower paying jobs. Furthermore, the populations of the segregated ghetto areas are clearly worse off in each respect than the populations of the inner cities as a whole. For instance, looking at the 100 largest central cities in 1990, 28 percent of the total population aged 25 years and above had less than a high school education, while 53 percent of the population in extreme poverty areas of the central cities (with 40 percent or more residents living below the poverty line) had not completed high school (Kasarda, 1993). 
However, these indicators are all cross-sectional - that is, they deal with a phenomenon at a given time. More significant are the trends, within which these indicators simply reflect one point. Good time-series analyses of the human capital position of inner-city inhabitants are rare. One exception is the work of John Kasarda (1985, 1989, 1993), who has documented an increasing disparity in educational level between city jobs and minority city residents, in what he and others call a skills mismatch. The result is an increasing disparity between the unemployment rates of central-city white and black males: For white workers who have not completed high school, unemployment increased from 4.3 percent in 1969 to 17.7 percent in 1982, while for black workers of similar educational attainment, unemployment increased from 6.6 to 29.7 percent over this period (Kasarda, 1985).

To gain insight into what has been happening, we must turn to studies of relevant population groups (especially African Americans), even though those groups are defined more broadly than inner-city groups and often do not include all labor-market participants (Smith and Welch, 1989; Jaynes, 1990; O’Neill, 1990). The key message of each study is that for African-American males, earnings - both absolute and relative to white malesincreased from 1940 on. However, beginning in the 1980s, the black-white income gap ceased to close in the aggregate, and for younger workers it actually widened. In each decade after 1940, African Americans entering the labor force were better educated, in terms of years of schooling, and the educational gap with whites closed substantially. By 1980 the gap in mean years of school completed by males aged 25-34 years had fallen to just over 1 year, in contrast to 3.7 years in 1940. The corresponding black-white earnings percentage rose from 48.9 percent in 1940 to 79.4 percent in 1980, but has since slightly declined (O’Neill, 1990).

Clearly, human capital had much to do with these gains. But June O'Neill (1990) and James Smith and Finis Welch (1989) argue that years of education alone were not sufficient. A substantial gain in the quality of education and in the resulting skills enabled new entrants to compete effectively in the labor market, though the gain seems to have ended by the 1970s. Since the 1970s, the returns from education seem to have been greater for whites and non-black minorities than for African Americans (Carnoy, 1994).

In the 1980s, two important and closely related changes occurred. First, the overall premium of higher education increased sharply, although the required skills were often not used on the job. In essence, the educational ante for jobs increased, creating a downward substitution effect, as college-educated labor moved into jobs formerly occupied by those with only a high school education, and so forth down the line (Carnoy, 1994). However, along with the increased premium, black-white differentials among the college educated widened: For males aged 25-34 years with a college degree, black-white weekly earnings percentages fell from 96 percent in 1977-79 to 74.4 percent in 1986-88 (O'Neill, 1990). At the same time, an increasing disparity between the unemployment rates of central-city white and black males with 1 or more years of college education appeared: For collegeeducated white workers, unemployment increased from 1.6 percent in 1969 to 4.4 percent in 1982, while for black workers of similar educational attainment, unemployment increased from 3.7 to 16.1 percent over the same period (Kasarda, 1985). The earnings value of additional higher education tended to favor whites, who also were more likely to work in high-skill occupations, suggesting that African Americans were not fully participating in the new information economy. This lack of participation, as well as the overall slowdown of African-American college attendance in the 1980s, led some to suggest that African Americans lacked access to jobs as "symbolic analysts" in the information-based sector (Reich, 1992; Carnoy, 1994). 
Second, since 1970, there has been a disastrous countertrend in the relative likelihood of black males being employed. As late as 1970, 94 percent of black male high school graduates were in the labor force. By 1985, that proportion had fallen to 85 percent. For whites, the corresponding numbers were 97 and 94 percent, respectively (Jaynes, 1990). For those African Americans with 4 or more years of college, the labor-force participation rate fell from 92 percent in 1970 to 86 percent in 1985. For those with 8 or fewer years of education, the labor-force participation rate fell from 85 to 61 percent, and only about one-half were employed. Moreover, when standardized for central-city residency, the disparity between the unemployment rates of white and black high school dropouts was even greater than for the country as a whole (Moss and Tilly, 1991). Although it is most likely that other factors on the demand side were at work here, it is clear that the role of human capital was powerful both in improving the position of minorities and in potentially limiting their gains.

We should be careful when applying analyses such as those cited above to the situation of inner-city populations. Nonetheless, it is clear that whatever human capital impacts occur in minority populations in general, the effects are likely to be worse among inner-city populations. Not only do they almost invariably have fewer years of education, but the schools that they attend also appear to be generally less effective in terms of educational attainment scores. At a time when the importance of further education for subsequent income appears to be increasing, their educational prospects are grim and their access to labor-market experience is declining. Whatever else may be affecting inner-city poverty, the significance of the human capital deficit cannot be ignored.

\section{Employment Discrimination: Denial of Opportunity}

If employment and earnings disparities among different population subgroups were only a matter of human capital differences, poverty could be alleviated by improving the skills of the labor supply to meet labor demand. But racial and gender discrimination undoubtedly interfere in the search for employment, preventing labor markets from adjusting properly. The hypothesis of this section, then, is that persistent discrimination increases and reinforces urban poverty.

Research on discrimination frequently focuses on the poor, but it is difficult to demonstrate the specific ways in which discrimination affects income levels. The most common model suggests that discrimination causes poverty by hindering the movement of qualified workers into employment and preventing the exodus of inner-city residents into suburban neighborhoods that have the schools and quality of life to promote upward mobility. But discrimination also plays an indirect role in causing poverty because it creates segregation and its attendant concentration effects on poverty; because it lowers wages for women, exacerbating the problems incumbent in female-headed households; and perhaps because it results in public policies, such as affirmative action, that create a backlash against minorities. Although discrimination appears in many different forums, from the labor market to the housing and financial markets and the criminal justice system, this discussion focuses on discrimination in employment. Discrimination in housing markets is discussed below in the spatial mismatch hypothesis.

That employment discrimination persists is an anomaly according to neoclassical economic theory, which predicts that it should eventually decline in the face of competitive pressures in the market. Theoretically, discriminators pay a premium to employ nonminority workers, and nondiscriminating firms should be able to hire minorities at lower costs and, therefore, become more competitive. Discriminators would be forced out of business_-at least in a tight labor market (Becker, 1957; Shulman, 1990; England and 
Farkas, 1986). In practice, however, employer preferences along with the tendency to use statistical generalization in hiring continue to result in discrimination. Preference discrimination occurs when the nonpecuniary satisfaction provided by certain groups is so high that employers pay the price - in terms of labor costs - of indulging that preference (Becker, 1957). Statistical discrimination allows employers to lower their search costs as they use a group identifier such as sex or race to predict job performance instead of determining actual individual differences in desired job traits.

Because the extent of employment discrimination is difficult to quantify, economists have focused on wage discrimination studies, which typically rely on large-scale national or regional data sets. Wage discrimination is typically measured by models that control for education, work experience, industrial and regional distributions, marital status, and number of hours worked. Such models have found that the extent of discrimination declined dramatically between 1940 and 1970, but the rate of decrease slowed after 1970, particularly for African-American males (Carnoy, 1994). The income gap between white and black males that is explained by discrimination decreased from about 35 percent in 1939 to 16 percent in 1984, rising again to 18 percent in 1989.

Discrimination fosters earnings disparities in part by increasing occupational segregation. In general, the higher the percentage minority or female in an occupation, the less the occupation is paid, and the more minorities or women are crowded into certain occupations, the more wages drop (England and Farkas, 1986). This wage gap is also affected by wage discrimination, as employers make differential payments for similar qualifications and job characteristics or set wages lower for minorities or females than for males in jobs that involve different tasks but make a comparable contribution to the firm's product (Reskin and Hartmann, 1986).

The question remains of why preferences for nonminority workers persist. Studies of employment discrimination are increasingly examining this question using survey and interview data from inner-city employers. Undoubtedly employer prejudices and racial stereotypes play a critical role in perpetuating discrimination, but researchers have documented a negative view of inner-city African-American workers, particularly males, among both white and African-American employers. ${ }^{3}$ For many inner-city employers, it is not the human capital deficit that disqualifies minority applicants but a perceived deficit in soft skills, such as motivation, flexibility, and interaction (Moss and Tilly, 1995; Neckerman and Kirschenman, 1991). Employers also seek to maintain good communication and cooperation within the workplace, as well as managerial control, and thus may perceive African Americans as risky to hire (Shulman, 1990).

Discrimination also persists because of occupational traditions. For instance, employers in the hotel and restaurant industries have traditionally separated the back-of-the-house labor-minorities who staff the kitchens and clean the rooms-from the front-of-thehouse labor - the mostly white receptionists and waiters (Bailey, 1987). Their acts of discrimination may result from the development of ethnic niches in certain occupations or industries where recruitment occurs mostly by word of mouth within the ethnic group, migration chains supply an endless pool of labor, and the niche prevails even when migrants and the minorities being discriminated against have comparable skills (Waldinger, 1996). Once such niches are created, they tend to demarcate opportunity structures, at least in the perception of urban residents, and the recurrent discrimination against certain racial or ethnic groups discourages them from applying for jobs in certain sectors (Waldinger, 1994; W.J. Wilson, 1996). 
Numerous studies have found evidence of discrimination in hiring, but researchers have had less success in determining the conditions under which it typically occurs. Paired-test studies in which minority job applicants were paired with white applicants with similar backgrounds and trained to be as similar as possible in behavior have illustrated employment discrimination, showing that minorities, particularly African Americans and foreignsounding Latinos, were less likely to receive job interviews and offers (Cross et al., 1990; Turner, Fix, and Struyk, 1991). ${ }^{4}$ A paired-test study of firms in which white-owned companies were compared with those owned by African Americans showed that the proportion of African-American workers was greater in black-owned firms (Turner, 1997). Interestingly, the incidence of discrimination might have been rarer in promotion hiring than in recruitment hiring: Once inside a firm, African Americans faced less discrimination in obtaining good jobs than outside applicants, controlling for education (Braddock and McPartland, 1987).

But whether the recruitment method itself promotes discrimination is still a matter of debate. The use of formal intermediaries, such as employment agencies, and objective screening, such as skills testing, may increase the representation of African Americans in a firm and is associated with hiring in large downtown companies and government agencies (Neckerman and Kirschenman, 1991). However, the most recent research has shown that the proportion of blacks is higher in firms relying on less formal screening mechanisms, such as the low-skill, low-wage, high-turnover restaurant and retail sectors (Holzer, 1995; Kirschenman et al., 1995). ${ }^{5}$ Another factor that may promote discrimination is the use of geographical hiring strategies; for instance, recruitment may be concentrated in white neighborhoods or targeted to certain ethnic groups using ethnic newspapers (Neckerman and Kirschenman, 1991).

The extent of employment discrimination is difficult to quantify, but the bulk of empirical tests point to its continued existence in labor markets and other arenas. The existence of discrimination helps to explain employment and earnings disparities between white and black (as well as male and female) workers of the same human capital attainment. Wage and employment discrimination clearly contributes to the chronic poverty of many innercity residents. The growing body of research focusing specifically on discrimination in the inner city should help elucidate just how critical the role of discrimination is.

\section{Cultural Behavior: The Underclass Debate}

In debates over inner-city poverty, few analysts question the significance of factors such as the changing demand for lower skilled workers, the lack of human capital, or the existence of discrimination in employment and housing, even though they may disagree on their relative importance. However, another theme of urban poverty has generated enormous disagreement. The question of how much the culture and behavior of the poor affect and perpetuate poverty has transformed itself into the debate over the underclass.

To turn F. Scott Fitzgerald on his head, it is not only the rich who are different from the rest of us. For many in this society, it is the poor who are seen as truly different and, in fact, the "other." The perception that the poor constitute a separate society, governed by their own code of values and behavior, is not a new one. Urban reformers in the 19th century, as they struggled to improve conditions in industrializing cities, often saw the poor, and especially immigrants, as needing the transformation of their values as much as improvement in their grim material conditions (De Forest and Veiller, 1903). Early reformers were not hesitant to condemn the poor as profligate, immoral, and shiftlessas cunningly taking advantage of their betters and refusing to recognize the virtues of 
Americanism, the Protestant work ethic, or the desirability of voting against corrupt political machines run by their ethnic compatriots. In all this, there was a flavor of the complicity of the poor in their own fate. However, these voices receded in the face of economic and social gains of the 20th century, especially after World War II. Even overt racism was muted, if not eliminated, by the civil rights movement of the 1960s.

Thus it may appear surprising that among the most powerful arguments about urban poverty to emerge in the 1980s was one that refocused the responsibility for poverty on the poor themselves. However, this modern version, too, was not without closer origins. Government attempts to alleviate urban poverty in the Third World during the early efforts at economic development in the postwar period had led to frustration and debate over its nature and causes. Among some sociologists and anthropologists studying development, the notion of a culture of poverty emerged (Lewis, 1959). The difficulty in creating the necessary behavioral changes for effective economic modernization arose from an interlocking complex of values, behaviors, relationships, and expectations that marked the social system in which the poor participated. Some argued that the thin line between starvation and life that was the daily lot of the urban poor, together with their suspicion of all public action, which was based on their experience of ruthless exploitation and repression, made such behaviors both explicable and rational. However, such voices disappeared in the storm of rejection of the cultural explanation for failing to take into account the structural context within which poverty occurs-notably imperialism and colonialism.

A similar debate briefly emerged on the U.S. domestic scene during the War on Poverty in the 1960s. Some suggested that the rapid expansion of the welfare rolls during that period might affect work motivation or create welfare dependency. However, they were greeted with responses of "blaming the victim," and the general belief that poverty could be addressed through income supplements, education, and job training prevailed over the next two decades, even though funding was never considered adequate.

The notion that culture and behavior might be important contributions to the persistence of poverty re-emerged during the 1980s. This was in part a response to the apparent worsening of conditions in the inner cities and in part a component of the conservative trend in public attitudes toward social expenditures, particularly welfare. The evident worsening of conditions for the inner-city urban poor stimulated William J. Wilson $(1987,1996)$ to put forward an evolving theoretical and empirical explanation that combined structural and behavioral factors. We discuss his structural views below, but the relevancy is that he also endorsed the view that structures of behavior among the core urban poor profoundly shaped their ability to change their economic situation. Wilson saw poverty in inner cities as driven by four critical elements: declining job opportunities, the changing structure of African-American families, outmigration of middle-income African Americans, and neighborhood effects that enhanced the intergenerational transmission of poverty. Of these, family structure and cultural peer group effects are the focus of this section, though the critical role of social and physical isolation should be noted.

The story was also taken up by conservative critics of welfare dependency, who saw welfare as creating incentives that were counter to individual economic advancement and that fostered long-term, multigenerational dependency (Gilder, 1981; Murray, 1984; Mead, 1986). Despite powerful, well-grounded counterarguments, these ideas deeply affected both Federal policy and public opinion, laying the groundwork for the attack on welfare programs in the 1990s. More immediately, they were connected to the emergence of a debate over the group that came to be called the underclass. Whether explained as due to rural origins (Auletta, 1982; Lemann, 1991) or through isolation and entrapment of 
the poor for structural reasons, such as racism (Glasgow, 1980), the underclass notion of poverty in the 1980s and 1990s focused on the existence of part of the population that is out of the economic mainstream. Living in areas that are isolated, segregated, and crime-ridden, this population is characterized by low labor-market attachment, low educational achievement, and a wide range of socially reproved behaviors, including welfare dependency, drug use, single-parent households, and engagement in the underground economy. As noted above, this idea is very familiar to anyone who has read the writings of U.S. urban reformers of the 19th century, whose mixture of concern and disapproval is reminiscent of current views. However, there are important differences. One is the existence of welfare support as an option, albeit one that is under heavy pressure from the welfare reform legislation of 1996. The second difference is the existence of strong voices critical of the underclass idea, which are discussed below. Nonetheless, the recent influence of the underclass notion on politics and policy is undeniable, and the debate continues (Jencks and Peterson, 1991).

The existence of strong evidence on either side of the issue is less clear. In part, this may be because the debate has largely taken place among sociologists and anthropologists whose research style, in many instances, is not easily translated into generalizable conclusions on cause and effect. A great deal of work seeks to document the existence and to measure the extent of the underclass, as well as to gain a phenomenological sense of the lives of the group's members (Wilson and Aponte, 1985; Mincy, 1994). Ronald Mincy points out that the numerous efforts to define and measure the phenomenon have focused either on the individual/household unit or on the inhabitants of specific geographic subareas, typically census tracts, analyzing the region's poverty (that is, income status) or its multiple social problems. As a result, definitions and estimates of the size of underclass populations have varied wildly, from more than 500,000 to as high as 11 million people. The best definition of the underclass may be that advanced by Martha Van Haitsma (1989), who emphasizes the characteristics of labor-force detachment and derivation of income from sources outside of the formal economy, rather than deviance from norms or social dysfunction.

This definition, however, differs from the widely used definition of the underclass as "people whose behavior departs from [mainstream] norms," including high school dropouts, young males detached from the labor force, female heads of households, and welfare recipients (Ricketts and Sawhill, 1988). Herbert Gans (1995) points out in his recent work on antipoverty policy that this definition rests on the suspect premise that these behaviors violate norms. Yet some members of these underclass groups may drop out of high school to support their families or may be unemployed rather than "detached," or may be single mothers because of the lack of eligible males, or may participate in Aid to Families with Dependent Children (AFDC) to supplement other income sources, as described below. Rather than emergent underclass categories, these groups, particularly the female-headed households, are demographic and economic groupings, resulting from the lack of well-paying, low-skill jobs, the persistent wage gap between men and women, and the incarceration of a substantial portion of the young African-American male population (Wilson, W.J., 1987, 1996).

How the various elements of underclass behavior actually affect inner-city poverty is less clear. Economists have extensively studied income distribution and populations in poverty, but the limitations on data have generally prevented them from detailed study of how choices about education, childbearing, marriage, and work are made among core underclass populations. Thus, although much can be said about the behavior of people 
on welfare, the analysis is much weaker on the question of ghetto populations. David Ellwood (1998), perhaps the foremost economic analyst of welfare, points out:

Some evidence suggests that the poor in ghettos, though they are only a small proportion of the poverty population, are different in important ways. Ghettos are disastrous places to live. The worst problems of the society are found in very disproportionate numbers there. The ethnographic literature leaves no doubt about the desperation one finds there. Therefore the ghetto, while not a huge part of the welfare problem, is nonetheless a major social problem, and one about which information is sporadic and somewhat inconsistent.

In particular, neighborhood effects, in the aggregate, are not well understood beyond the recognition that they exist in relation to crime, academic achievement, and childbearing (Case and Katz, 1990; Crane, 1991; see also the next section).

Sociologists and anthropologists have been very effective in their studies of the life situations of people in poverty (Liebow, 1967; Rainwater, 1970; Kelly, 1994; Bourgois, 1995). The picture they paint is less one of aberrant values and more one of functional adaptation to an extraordinary environment in which the normal signals of middle-class American life simply do not exist or apply. As a result, there is a certain ambiguity about their explication of poverty. If the inhabitants of the ghetto are essentially powerless and constrained by the larger society through exploitation and racism, their plight can respond only to fundamental social changes. However, even when researchers, such as Loic Wacquant (1997), are most intent on denouncing the errors of the advocates of the underclass hypothesis, they still find themselves dealing with a profoundly difficult social environment. Eliminating the notions of pathology or social disorganization does not change the realities of ghetto life.

Whether long-term exposure to such an environment leads to fundamental shifts in the norms and values of its inhabitants is much debated. Whether change can be achieved, for example, by limiting welfare, improving schools, or providing employment, without changing both the environment and its associated behaviors, still marks the line between conservative and liberal assessments of appropriate policy. Nonetheless, the environment of the ghetto seems indisputably to be inimical to behavior that would enable its populations to raise their incomes and participate more fully in the economic mainstream.

\section{Segregation, Housing Discrimination, and Spatial Mismatch: Space Versus Race}

The fifth hypothesis suggests that the decentralization of employment and increasing residential segregation work in tandem to limit the accessibility of jobs for inner-city residents, thereby isolating them and trapping them in poverty. In essence, it maps onto intrametropolitan space the first hypothesis - that structural changes in the economy have caused poverty. This theory of spatial mismatch argues that while firms offering low-skill jobs, particularly in manufacturing, have left the inner city for the suburbs, their minority work forces have not followed, because both discrimination in housing markets precludes their residential mobility and the costs of commuting and acquiring job search information inhibit access to job opportunities. Furthermore, as the suburbanization of jobs and the middle class increases segregation, inner-city residents become isolated from the economic and cultural mainstream.

As put forth originally by John F. Kain (1968) and subsequently developed by others (for example, Kasarda, 1985; Wilson, 1987), the spatial mismatch hypothesis argues that suburbanization of low-skill jobs (particularly in manufacturing) and housing market 
discrimination are primarily responsible for the growing employment problems of those who continue to live in the inner cities, especially African Americans. As firms move to the suburbs, the minority labor supply is slow to adjust. Inner-city residents have difficulty following the jobs because of racial barriers to residential location in suburban housing markets, and their access to jobs becomes more problematic as the cost of travel rises, lowering net wages. At the same time, the effectiveness of their information networks to learn about job opportunities decreases, raising their job search costs. Substantial evidence exists that segregation of the poor increased from 1970 to 1990, even as racial segregation generally declined (Abramson et al., 1995).

The spatial mismatch hypothesis seems to be withstanding a number of empirical tests over time (Ihlanfeldt and Sjoquist, 1989, 1990; Holzer, 1991; Peterson and Vroman, 1992; Kain, 1992). However, even mismatch theorists (such as Kain, 1992; Kasarda, 1989) concede the continued importance of race and locality in determining the availability of job opportunities. For instance, suburban job growth tends to occur in areas distant from suburban areas with new black occupants (Galster, 1991a; Schneider and Phelan, 1990). Moreover, when integrated firms relocate to suburbs, their white employees are much more likely to follow than are their black employees (Zax and Kain, 1992). Discrimination in employment persists even when minority workers have good geographic access to opportunities (Turner, 1997). Overall, industrial transformation has a far greater impact on job prospects for inner-city residents who are African American than for those who are white (Kasarda and Ting, 1996).

Place, that is, the economic characteristics and size of the region, also may determine the extent of the spatial mismatch phenomenon. When the regional labor market is tight, and aggregate demand for labor is high, the mismatch is less extensive (Kain, 1992). In regions where minority residents have traditionally been underrepresented in the manufacturing sector, such as African Americans in New York City, the impact of the decentralization of manufacturing jobs on their job prospects is far less (Fainstein, 1986). The explanatory power of the spatial mismatch also varies by metropolitan area size: In small cities, only 3 percent of the gap between black and white employment rates is explained by inaccessibility to job opportunities, whereas in large cities, 25 percent of the gap is explained by the mismatch (Ihlanfeldt, 1991).

Recently, research has begun to focus on transportation and information mismatches. Proponents of the automobile mismatch point to the higher commute times of the lowincome inner-city residents who are "transit captives," suggesting strategies to improve transportation or to relocate inner-city residents to the suburbs (Taylor and Ong, 1995; Hughes, 1995; Rosenbaum, 1995). Information mismatch theorists counter that mobility strategies have little impact, because people often find jobs through social networks that are frequently spatially situated (Hanson and Pratt, 1995). In this view, space is a factor not only because of the proximity to employment but also because the extent of segregation in the residential area affects the composition of the social network that often leads to job opportunities (Braddock and McPartland, 1987; Wilson, W.J., 1996).

Key to the spatial mismatch argument is discrimination in the housing market, which prevents the low-skilled labor force from following jobs to the suburbs and maintains racial segregation in both cities and suburbs. Thus discrimination not only creates barriers to social mobility, because minority residents have fewer opportunities to improve life chances by moving to better neighborhoods with better schools, but also creates racial segregation. And because the increase in poverty rates caused by industrial transformation is disproportionately concentrated in a small number of neighborhoods, segregation in 
turn becomes an important cause of poverty, both through the creation of neighborhood effects and the isolation of segregated space (Massey and Denton, 1993).

The most important consequence of housing discrimination is segregation. If discrimination were eliminated, segregation would decline by at least one-fourth and perhaps by one-half (Galster, 1992, 1996). Housing discrimination not only prevents minority innercity residents from buying homes in white neighborhoods, which are safer and provide better quality schools, but also discourages homeseekers from even looking in such neighborhoods. And the incidence of housing discrimination has not decreased significantly since it was first studied in the 1970s. When paired testers posed as home or apartment seekers in a recent HUD study, discrimination, albeit sometimes subtle, occurred in approximately one-half of all interactions with real estate agents (Galster, 1992; Turner, 1992). The most prevalent form of housing discrimination was racial steering: A significant proportion of African-American clients were steered to neighborhoods that were less white, lower income, and had lower property values (Turner, Struyk, and Yinger, 1991). Paired testers used in mortgage-lending studies have found that minorities are steered toward government-insured loans and are more likely to be denied loans, even when controlling for factors such as greater indebtedness, lower downpayments, and weaker credit histories (Galster, 1996; Munnell et al., 1992).

Neighborhood effects (Jencks and Mayer, 1990b) or concentration effects (Wilson, W.J., 1996) occur as poverty is increasingly concentrated in certain neighborhoods. As the incomes of neighborhood residents decline to levels unable to support a viable retail sector or to maintain housing, a spiral of abandonment and decay begins. When the area becomes a high-poverty neighborhood (typically with 40 percent or more poor households), average educational attainment levels decrease (Datcher, 1982; Corcoran et al., 1987) and teenage pregnancy and high school dropout rates may increase dramatically (Crane, 1991).

Segregation itself causes poverty because it increases, by as much as 33 percent, the probability that a young black man does not work (Massey et al., 1991). If segregation were to decrease, so would the poverty rate, the high school dropout rate, and the homicide rate (Galster and Keeney, 1988; Galster, 1991b; Peterson and Krivo, 1993). In fact, recent research has shown that as little as a 1-standard-deviation decrease in segregation would eliminate one-third of the black-white differences in life experiences, such as dropping out of high school, lacking a job, or becoming a single parent (Cutler and Glaeser, 1997). But segregation also contributes to poverty in more indirect ways: As financial, information, and human resources are depleted, the development of human capital and the transmission of information about job opportunities is hindered, and as interracial suspicion increases, so do discriminatory barriers (Galster, 1996).

The spatial mismatch and segregation hypothesis perhaps raises more questions than it answers. If the low-skill manufacturing jobs departing the city have left a large labor supply behind, why has it not been absorbed by the growing financial and business service firms that dominate downtown? Is it because these information-based, knowledgeintensive, white-collar service industries require greater levels of human capital (Bell, 1973; Kasarda, 1985; Noyelle, 1987) or because all that remains in the core are undesirable low-wage jobs (Sassen, 1991; Castells, 1989)? How are the effects of the three dimensions of access - space, information, and transportation—related? And even with perfect access, in terms of spatial proximity, information networks, and physical mobility, would the mismatch be perpetuated by employer discrimination? 


\section{Migration: A Two-Sided Phenomenon}

The poor and ambitious continue to move into cities in search of a better future, while middle-class residents leave for a better quality of life in the suburbs. Cities continuously reconstitute themselves, as the newcomers fill the economic niches and social structures vacated by the departing residents. While this process of regeneration may benefit the most mobile individuals, it arguably hurts city residents who make up the stable core of the population - the residents who will not, because of community attachment, discrimination, or lack of information about job and housing opportunities, leave the city. Poverty for these residents results from both the depletion of resources in their communities, as the successful members and potential role models depart, and the competition for jobs in their cities, as more recent immigrants are better able to capitalize on economic opportunities.

The argument that migration causes poverty rests on several assumptions: that a sense of community is vital to the social and economic well-being of city residents, that outmigration depletes social capital and thus the ability and/or willingness to participate in city political and economic institutions, and that in-migration allows more recent arrivals to displace older residents from the labor force and the housing market.

The idea of the importance of community in the modern city stems from the Chicago School, a group of sociologists at the University of Chicago who, building on the work of Max Weber and Georg Simmel in Germany, essentially launched the U.S. field of urban sociology in the 1920s. Theorists such as Robert Park (1969) and Louis Wirth (1969) argued that the advent of industrial urbanization relaxed or destroyed the relationships and rules of the social organizations that constitute communities. As instrumental secondary ties (of economic interest) substituted for sentimental, face-to-face relations based on family ties, culture, and status, the sense of group solidarity diminished, along with the community control of behavior and norms.

While this loss of community was originally blamed for the lack of social purpose in society (Nisbet, 1976) and the lack of civic engagement in society (Bellah et al., 1985), it has increasingly been associated with reducing the social capital available in the inner city, thereby causing poverty (Wilson, W.J., 1996). Social capital, a concept popularized by Robert Putnam (1993) but developed by Coleman (1988, 1990), essentially consists of the relationships between actors who engage in social exchanges that create mutual dependence and expectations. In effect, it is the social resources for getting things done. Such capital may come in a variety of forms, such as obligations and expectations, information potential, norms and sanctions, and relations of authority; but it always resides in relations, not in individual human or financial capital (Coleman, 1990). Social capital is created by bounded solidarity, such as the group definition provided by ethnicity, and enforceable trust, based on the accumulation of obligations (Portes and Sensenbrenner, 1993; Portes and Zhou, 1993).

The depletion of social capital in the inner city occurs when the middle class departs for the suburbs, leaving behind few residents who can offer social resources, such as providing role models to neighborhood youth and access to social networks that transmit job information and create mutual trust between potential employer and employee. In the 1970s, urban fiscal crises brought attention to the suburbanization of middle-class whites (and their tax dollars), but in the 1980s, the increase in urban poverty, with its disproportionate impacts on African Americans, led William J. Wilson to focus on the importance of the outmigration of the middle-class blacks. In The Truly Disadvantaged (1987) and 
later in When Work Disappears (1996), Wilson suggests that the departure of AfricanAmerican households creates concentration effects-or the spatial and social isolation from mainstream behavioral norms that cause high rates of unemployment, crime, welfare dependency, family atomization, and adolescent pregnancies. Elsewhere, this departure has been characterized as a crisis of leadership, as the black middle class has cultivated values of "professional conscientiousness, personal accomplishment, and cautious adjustment," at the expense of "a collective and critical consciousness and a moral commitment to and courageous engagement with causes beyond that of one's self and family" (West, 1993).

Yet does the exiting middle class actually deplete the supply of social capital in the inner city? Or are the relations of mutuality (remarkably) still intact but without any resources to share (Kelly, 1994)? The vast majority of residents of concentrated poverty neighborhoods lack financial resources, and mutual obligations cannot be created if individuals have insufficient resources to pay into the favor bank. Moreover, the isolation of innercity neighborhoods makes it less likely that social networks will include the weak ties that are most efficient at providing information about job opportunities (Granovetter, 1973).

A diverse body of empirical work sheds doubt on the explanatory power of the departure of the black middle class. The poor are actually more likely to leave poor neighborhoods than the nonpoor, and the nonpoor typically leave poor neighborhoods for other poor neighborhoods, suggesting the continued importance of racially segregated housing markets (Massey et al., 1994). Survey research has found that the meaning of community, in the sense of belonging to identifiable community with a common purpose, is higher in neighborhoods that have a majority of African-American residents, due to the fact that in such areas they actually are no longer minorities (Portney and Berry, 1997). Other research has focused on the relative roles of social and human capital. James Johnson, Elisa Bienenstock, and Jenifer Stoloff (1995) have developed a set of proxies for cultural capital (geographical location; family background; educational, religious, and political influences; and ethnic identity) and find that negative effects on employment status disappear once human capital and social status variables are controlled for. Timothy Bates (1994) finds that human capital is positively related to the success of Asian entrepreneurial businesses, but reliance on social support networks is associated with lower profits and higher failure rates. J.M. Sanders and V. Nee (1996) argue that factors of human capital and class resources combine with social capital embodied in family relations to determine the success of immigrant entrepreneurs.

Inmigration is also seen as playing a role in causing poverty, by creating crowding in neighborhoods and occupations. One root of today's inner-city poverty can be traced back to inmigration of blacks from the rural South during the World War II era, when the small, relatively integrated and socially organized communities of the northern cities (see, for example, Drake and Cayton, 1945) became large, relatively segregated ghettos. The newcomers undercut the position of the older African-American residents by competing for jobs and reinforcing negative stereotypes of character deficiencies stemming from slavery (Lieberson, 1978). ${ }^{6}$

Inmigration has also contributed to inner-city poverty. New immigrants are able to find special occupational niches, capturing the new low-skill jobs that are being created in cities in both retail and low-wage manufacturing (Waldinger, 1996). Local labor markets are made up not only of long-term residents of the area but also of immigrants who form migration chains to areas where ethnic groups have become embedded in industrial sectors (Granovetter and Tilly, 1988). Racial and ethnic labor market niches give specific groups privileged access to jobs, as employers increasingly hire within the same group 
to facilitate training and work force stability (Waldinger, 1996). The resultant racial or ethnic labor-market segment is reinforced as groups exclude outsiders from job referral networks.

Empirical studies of racial and ethnic labor market niches in Chicago, Los Angeles, and New York have shown the importance of such niches in determining employment outcomes. Roger Waldinger's (1986) research on the ethnic division of labor in the New York City garment industry found that the fiscal crisis of the 1970s lowered wages, causing whites to drop out of the labor supply. He finds that, because native-born blacks and second-generation Puerto Ricans were not interested in joining the labor queue at such low wages, firms recruited Asian and Hispanic immigrants who brought special skills and social networks that effectively created occupational closure around these new immigrant groups. For example, in Red Hook, Brooklyn, employers relied on referrals from ethnic groups such as Irish, Mexican, Polish, or Spanish immigrants who typically lived in Queens or New Jersey (Kasinitz and Rosenberg, 1993). Given employer resistance to hiring locals, both social networks and local public agencies led Mexican Americans in the Pilsen neighborhood of Chicago to larger employers in other areas (Mier and Giloth, 1985).

Despite the exclusion of different racial and ethnic groups from various labor-market niches, it is not clear to what extent new immigrant labor is substituting for native-born minority labor rather than complementing it. Most studies indicate that the influx of foreign-born labor has a complementary effect, expanding the demand for native workers as skills such as English competency become more valued (see, for example, Altonji and Card, 1990) or as workers simply undergo a different process of labor-market integration and mobility (Bailey, 1987). Others suggest that some substitution effects may be occurring - that immigration of low-skill workers increases joblessness for African Americans (Ong and Valenzuela, 1996) and women (Bailey, 1987) of comparable skill levels.

Inmigration may also cause poverty as new housing demand from gentrifying urban professionals displaces low-income residents and exacerbates an already tight housing market. Whether gentrification stems from consumer preference based on demographic factors and lifestyle changes (Berry, 1985) or from the need of downtown growth coalitions to rationalize their investments in the inner city (Smith, 1982, 1996), it undoubtedly has turned low-income communities into contested turf, as upper-income newcomers seek to renovate the low-income housing located so conveniently near downtown (Abu-Lughod, 1994).

It is unlikely that new empirical work will fully answer the question of whether the decline of community or the depletion of social capital contributes significantly to poverty in the inner city. Social capital is clearly important, but it also seems to work in tandem with access to other resources, particularly human and financial capital. Likewise, research on immigration indicates that it contributes to inner-city poverty, but more research is needed to determine the extent of its impact.

\section{The Endogenous Growth Deficit: Growing From the Ground Up}

Most hypotheses about urban poverty concentrate on labor supply. On the demand side, the loss of employment in central cities, attributable to larger shifts in regional and national competitiveness and changing technologies, forms a general backdrop to most discussions about inner-city poverty. Nonetheless, the bulk of research focuses on the poor themselves, either as lacking the human capital or appropriate cultural resources 
necessary for full participation in the economy or as affected by racial discrimination or their inability to seize employment opportunities. However, there is another side to the issue of employment in the cities, namely, the capacity to generate new jobs by providing an environment in which businesses can start up and grow. If inner-city poverty is, in part, the result of lack of demand for labor, we may hypothesize that part of that lack is due to a deficit in the creation of new firms. In this section we focus on whether such a deficit exists and, if so, what form it takes.

The field of local economic development has undergone many changes in the past two decades, but none is greater than the shift in perceptions about what is fundamental for growth at the regional and local levels (Eisinger, 1988; Blakely, 1989; Teitz, 1994). Historically, efforts to develop local and regional economies in the United States largely revolved around attempts to attract external investment, usually through branch plants of large firms. This strategy has not disappeared, as is evident from competition among States and localities to attract new automobile assembly plants. But since the intense recession of the early 1980s, with its massive permanent losses of employment in the older sectors and industrial regions of the country, the prospects of this strategy have dimmed. Neither the hitherto normal process of postrecession employment recovery nor the prospects for attracting new plants appear to work any longer. Faced with an apparent structural change in the economy, States and communities have sought to ensure their future by turning to what Peter Eisinger (1988) called "demand-side strategies" and what others have called autonomous local economic development (Teitz, 1994). These strategies draw on the debatable but widely accepted perception that most new employment in the U.S. arises as a result of the creation of new small firms that, in many cases, are the harbingers of entire new sectors and industrial clusters. The extent to which new employment is actually generated by small, growing firms has been fiercely debated (Birch, 1987; Harrison, 1994). Nonetheless, whole new sectors of the U.S. economy have indisputably arisen, especially in the realm of information technology, and they seem to be providing much of the economy's dynamism. Such growth is epitomized in regions like the Silicon Valley, where entrepreneurship, venture capitalism, and a densely networked business environment have created the most successful form of economic development in the late 20th century (Saxenian, 1994).

For older industrial cities, and especially their ghettos, this phenomenon sends a mixed message. The loss of traditional industrial employment and the rise of advanced business services seem to leave few opportunities for employment of unskilled and semiskilled workers, except in other low-paying service sectors. If such cities could tap into new wellsprings of entrepreneurial activity in their population, perhaps some of the impact of job loss could be alleviated and new sources of economic dynamism could be identified. Localities have widely adopted such strategies, creating programs for the support of small enterprise, developing loan funds and other sources of capital, initiating business incubators and enterprise zones, and declaring small business a key element of their economic development strategies (Blakely, 1989). On a broader scale, the call occasionally arises for a renewal of private business as the way to alleviate the social problems of inner cities. The most recent is a thesis by Michael Porter (1995) that emphasizes inner cities' locational competitive advantage and advocates deregulation and the downplaying of social investment, rather than small or minority enterprise. Unlikely as these ideas may sound, there is evidence that they are possible. Newly arriving immigrant groups, notably from Asia, have created endogenous growth in their communities reminiscent of earlier waves of immigrants to the cities, and there does seem to be some reinvestment by large retail and wholesale firms in inner-city locations. But is such a prospect realistic for 
ghettos? Does a growth strategy based on inner-city competitive advantage ignore the potential of inner-city residents and community-based organizations, as Porter's critics contend (Harrison and Glasmeier, 1997; Butler, 1996; Dymski, 1996; Thomas, 1996)?

The issue of entrepreneurship among nonimmigrant minorities, especially African Americans, is not a new one. As ghettos sank deeper into economic and social difficulties, observers recalled the vibrancy of Harlem and Chicago's Black Belt in the 1920s or after World War II. Despite deep poverty and unremitting discrimination, those communities exhibited a level of social cohesion and opportunity reminiscent of the lost communities of the preindustrial era. Although there were always absentee owners and enormous obstacles, successful black businesses did exist in numbers that could significantly affect the lives of ghetto inhabitants. Yet in the period of improved economic and social opportunity after World War II, minority business startups and ownership in inner cities lagged. The reasons were many and much debated. Social problems such as crime and drug dependency created a difficult environment for legitimate enterprise and diverted potential entrepreneurs to the illegal and informal economies. Employment opportunities, especially in government, that had resulted from advances in civil rights created a form of mobility for the aspiring African-American middle class that diverted them from business (Kasarda, 1990; Waldinger, 1996). As discussed earlier, that group took advantage of the opportunity to move to suburban areas, albeit largely segregated, just as others in the society were doing. As a result, the ghetto was deprived of potential entrepreneurs. Those people who were left presented a smaller, poorer, more risky market, from which both local and nonlocal enterprises, such as banks and supermarket chains, progressively withdrew. Such opportunities as did exist in this risky environment were often taken by immigrant groups, with whom relationships were at best complicated and at worst problematic, as was clear from the experience of Korean merchants during the Los Angeles riots of 1992 (Baldassare, 1994).

Whether the principal causes were changes in the environment for enterprise or the sectoral and geographic movement of key parts of the population, for those local entrepreneurs who remained, the obstacles to success were formidable (Bates, 1995). Entrepreneurs embody human capital in the form of ideas, energy, desire, business competence, and experience. Would-be minority entrepreneurs certainly have ideas, energy, and desire, but in comparison with other groups, they often lack the family background in business, which is so often important for success, together with the training that provides competence in business management. They also lack capital and contacts from family and other informal sources that are necessary for business startups, and they suffer from discrimination in lending and in access to opportunities that might offset some of these drawbacks. They also must operate in a social environment of crime and poverty that places enormous difficulties in the way of legitimate enterprise. It is, perhaps, not surprising then that the evidence from anthropological research suggests that illegal and informal economies too often provide the avenues for "success," albeit at great social and human costs (Bourgois, 1995).

We should not view this picture as complete. Despite the obstacles, minority entrepreneurs have managed in many instances to build profitable and successful businesses within the inner cities (Boston and Ross, 1996). Yet notwithstanding public policy efforts to stimulate minority business enterprise through programs such as those of the U.S. Small Business Administration, minority businesses in general are fewer, smaller, and more prone to failure than others (Boyd, 1990), and these statements are even more likely to ring true for those in the ghetto. 
There is little doubt that an entrepreneurship and business deficit exists and is related to poverty in the inner cities. Its scale and impact, however, are difficult to assess. Indeed, the argument can plausibly be made that causality runs in the opposite direction-that poverty and its attendant manifestations are the principal reasons for the lack of local enterprise and of external investment. Nonetheless, it is difficult to disagree with the proposition that opportunities for employment for inner-city residents can be enhanced by strong local enterprises. The issue is how to strengthen these enterprises. Policies to stimulate autonomous local economic development have much to be said for them, though there is as yet little evidence that they can make a difference in the inner cities with the greatest deprivation. Perhaps their greatest importance may turn out to be their part in a larger effort to create opportunity at the neighborhood and community levels through programs such as those associated with HUD's Empowerment Zone initiative. Policies, such as those advocated by Michael E. Porter (1995), that envision economic renewal through private capital investment enhanced by public policy in relation to regulation and the labor market are immediately criticized that they promise little to local residents and will generate neither wealth nor business ownership for minorities. Our sense is that, at this time in history, U.S. cities need but cannot afford to depend on external investment to provide continuing economic dynamism. As in the past, it is as engines of innovation and growth that cities must hope to survive and prosper, but that can hardly happen without continuing efforts to improve the standing of local entrepreneurs.

\section{Public Policy: The Helping Hand?}

Behind each factor causing urban poverty—whether it be industrial transformation, human capital, discrimination, the underclass, the spatial mismatch, migration, or the endogenous growth deficit-stands public policy. For instance, industrial transformation was facilitated in part by changing trade policy; human capital deficits were created in part by decreased public spending on education; and migration patterns were shaped by changing immigration laws. But perhaps no public policies have been so instrumental in actually increasing the incidence of urban poverty as Federal programs that shaped metropolitan development, such as urban renewal and highway construction, and policies intended to help alleviate poverty, including public housing and welfare.

Since the spatial policies that have facilitated suburbanization and rebuilt the inner cities arguably have helped to raise some out of poverty, while hindering the mobility of others, they are discussed here only in passing. These Federal policies have indisputably affected poverty indirectly, through their effects on migration, the spatial mismatch, and the underclass. Without the Federal aid for homebuying and highway construction, the middle-class exodus could not have occurred on such a great scale (Jackson, 1985). Without the concentration of publicly built low-income housing in the inner city and the weak Federal enforcement of antidiscrimination legislation, other (minority) population segments might have been able to follow jobs more effectively (Massey and Denton, 1993). The evidence lies in the uneven distribution of poverty and in the disproportionate increase in the poverty rate in older U.S. inner cities relative to newer suburban areas, particularly in the Sunbelt (Glickman et al., 1996).

While Federal policies shaping metropolitan development affected the distribution of poverty among and within regions, particularly in the Northeast and Midwest, Federal policies targeted at the impoverished population had their greatest impacts within the traditional ghettos of the older inner cities. Public antipoverty policies took the form of public housing provision, transfer income, education policies, and transportation assistance but, as in the academic literature on public policy and poverty, this section focuses on housing and welfare programs. 
The primary reason that public housing has (arguably) contributed to poverty lies in its origins: the Federal urban renewal program. While the policy goal of the 1949 Housing Act was "a decent home and a suitable living environment for every American family," its public purpose was to eliminate bad housing, not to rehouse slum dwellers. In effect, urban renewal was to eliminate blight, or declining property values, not to clear and rebuild slums for their residents. By placing urban renewal under the rubric of a housing program, downtown development interests gained the much-needed support of progressive advocates for low-income housing, thereby co-opting their opposition (Weiss, 1980).

Because participation in the Federal urban renewal program was voluntary, the extent of public housing construction varied across and within regions. Many municipalities, particularly in suburban areas, chose not to participate in urban renewal, whereas the ones that did, typically older inner cities with a pre-existing impoverished population, gained a disproportionate concentration of public housing (Jackson, 1985). Within these cities, planners tended to locate new housing within or adjacent to black neighborhoods out of political expediency, as elected officials typically wielded veto power over site selection (Meyerson and Banfield, 1955; Massey and Denton, 1993; Hirsch, 1983). By the 1960s, the Brooke Amendment led housing authorities to begin admitting welfare recipients and other destitute groups, instead of focusing on the working poor (Jackson, 1985). The result of these political factors was that the low- to medium-density housing of the inner cities was replaced by high-density towers and formerly working-class neighborhoods became segregated by race and income on an unprecedented scale (Massey and Denton, 1993). For the first time, the governments were clearly at fault for "making the second ghetto," or reinforcing patterns of segregation (Hirsch, 1983).

The idea that public housing policy causes poverty became legitimated by the judicial branch by the Gautreaux case in the 1970s, in which the Chicago Housing Authority was charged with discrimination because 99.5 percent of its units were in African-American or racially changing areas. Gautreaux required the housing authority to build public housing in white areas, and construction came to a standstill, but a 1976 Supreme Court consent decree created the Gautreaux program, which allows and assists public housing residents to relocate to white areas in the city or suburbs, using Section 8 certificates. That concentrated urban public housing has indeed reinforced poverty has been shown by subsequent studies of the program, which have shown that residents who have moved to suburban areas have higher employment rates and higher educational attainment than urban movers (Rosenbaum, 1995).

While few disagree about the role of public housing in relation to poverty, scholars are still debating the relationship of AFDC - now Temporary Aid to Needy Families (TANF)—-to poverty. In the 1980s, conservative theorists (Murray, 1984; Mead, 1986) advanced the argument that government assistance creates a permanently dependent population by eroding the work ethic and promoting social deviance, particularly promiscuity and family disintegration. As the AFDC caseload grew rapidly in the late 1980s and early 1990s (expanding by one-third from 1989 and 1993), elected officials adopted the idea that welfare itself was at fault for poverty to build political momentum for welfare reform (Duerr Berrick, 1995).

The initial critique of this welfare dependency viewpoint was developed by economists who pointed out that AFDC payments had declined in real value beginning in 1972 but the unemployment rate had doubled by 1980 (Greenstein, 1985; Danziger and Gottschalk, 1985). It also was unfair to point to AFDC as a cause of ghetto poverty, because fewer than 10 percent of welfare recipients lived in big-city ghettos (Ellwood, 1989). 
Subsequent research has been conducted mostly within the realm of sociology, using indepth interviews (Edin and Lein, 1996; Duerr Berrick, 1995; Waller, 1996). Given the sensitive nature of the subject—not only because of the stigma associated with welfare, but also because many recipients engage in unreported work - these data are probably more reliable than the large government-generated data sets typically used by economists in their analyses. In the course of almost 400 interviews in 4 cities, Kathryn Edin and Laura Lein (1996) report finding an overlap between groups of low-wage women workers and welfare recipients, since 60 percent of low-wage female workers had used welfare recently and about one-half of women on welfare worked-often without reporting it to the welfare agency. There was little difference between women who worked and women on welfare, except that the former had special circumstances that made work affordable, such as child support, low rent, few childcare or commuting costs, or full medical benefits (Edin and Lein, 1996; Duerr Berrick, 1995). Although the evidence about what caused women to leave welfare conflicted, the consensus was that almost one-half of exits were through work (Harris, 1993; Bane and Ellwood, 1994). In fact, Mary Jo Bane and David Ellwood found that actual work exits were higher than predicted by the rational-choice model. If welfare recipients were indeed dependent on supplemental income from work (among other sources) to make ends meet and caseloads shrank when the economy was strong (nationwide, welfare caseloads decreased 17 percent from 1993 to 1997), it is difficult to make the case that government assistance was creating a culture of dependency. As M. Patricia Fernandez Kelly (1994) said so eloquently:

Many impoverished people, living in racially segregated neighborhoods, express adherence to mainstream American mores; hard work, family loyalties and individual achievement are part of their cultural repertory. Nevertheless, the translation of values into action is shaped by the tangible milieu that encircles them. So, incidentally, is the ability of affluent families to actualize values into behavior.

\section{Conclusions}

Complex social phenomena rarely have simple causes, despite the assertions of those who claim to have answers to social problems. It is perhaps disappointing not to be able to point to one argument about inner-city poverty and say that it dominates all others. Yet one of the real benefits of social science is that it forces us to consider complexity. That may be unwelcome to advocates of particular policy prescriptions, but it is often the rock on which those prescriptions founder. There is still much that we do not know about the nature and causes of deep urban poverty in the United States, but this review suggests that much is known and that it is not a simple issue. There is substantial, if uneven, evidence that elements of all eight hypotheses contribute to inner-city poverty in a significant way. What we do not know is the relative importance of each hypothesis. Furthermore, at this stage in the development of social science, there is no way to know. Thus if we want to say something about their relative weight, we must rely on experience, intuition, and judgment. ${ }^{7}$

From the evidence of the hypotheses, some things do stand out. The inner-city poor do lack human capital to a profound degree in comparison with other groups. They are segregated and detached from the labor market. Demand for their skills at manual labor has declined. They face discrimination in employment and housing. They live in a social milieu that reinforces detachment from the mainstream economy, though how much that milieu results in a different set of values and behaviors is subject to much debate. Similarly, segregation has separated the inner-city poor physically from employment opportunities, but there is no clear agreement about the impact of that separation. Their communities have weakened in the past four decades, but whether this is due to 
outmigration by the middle class or has resulted in that migration has not been determined. They face competition from new immigrants, but these immigrants also create employment opportunities. Their communities do not generate new businesses, but whether that deficit is crucial for employment opportunity is not known. Finally, they have disproportionately experienced negative effects from public policy, but whether this has made the critical difference is probably not measurable.

Can we assess the relative causal strength of each of the eight hypotheses? In a crossdisciplinary context, an assessment can only be done judgmentally. Nonetheless, it looks as though conventional wisdom, in this instance, may be correct. We would assign the greatest weight to the first two hypotheses: industrial transformation and human capital. Without employment opportunities and adequate human capital, there is little prospect that the situation of the inner-city poor will improve. Following these two causes, our assessment is that the evidence shows that segregation, the spatial mismatch, and employment discrimination are very significant factors. In general, we are inclined to give less weight to migration and cultural behavior as explanations. However, the role of the social system within which the inner-city poor live remains open to debate. Whether it constitutes an iron cage or a rational adaptation to a harsh environment, and whether (and how) it must change before poverty can be alleviated, are now in the realm of ideology, though good ethnographic research is revealing the weaknesses of some underclass arguments. The question of endogenous growth in low-income communities appears to be important, but it is sadly deficient in rigorous research. Finally, we see public policy as a contributing but not a dominant factor that, in principle, can be alleviated.

Even more debatable are the policy measures that might reduce urban poverty. To suggest policy approaches is not the purpose of this article. Our sense is that policy advances are possible in most of the areas discussed, though the industrial transformation that destroyed the employment bases of inner cities is effectively irreversible and efforts to transform people's behavior without changing their material circumstances are probably futile. However, it must be stressed that, the fact that inner-city poverty is demonstrably complex and resistant to change does not imply that equally complex policy responses are the only way to proceed. Such responses are likely to collapse under their own weight, either during the legislative process or in their implementation. Given that poverty is remarkably complex suggests that it requires a sophisticated response strategy that takes into account its complexity but relies on multiple and simple elements for implementation. If the War on Poverty was not won, perhaps that is because, like all wars, victory requires a strategy that combines a deep understanding of the environment within which the war is waged and the willpower, resources, and weapons to do the job.

\section{Authors}

Michael B. Teitz is director of research at the Public Policy Institute of California and Professor of City and Regional Planning at the University of California, Berkeley. His major areas of work have been housing, especially rent control, and regional and local economic development.

Karen Chapple is a Ph.D. candidate in the department of city and regional planning at the University of California, Berkeley. Her dissertation examines the job-search strategies of low-income women and the geography of low-wage labor markets.

The authors are grateful for support provided by HUD and the Public Policy Institute of California. We received helpful comments and suggestions from Mark Baldassare, Melvin Webber, Norman Glickman, and John Ross. 


\section{Notes}

1. We are indebted to Mark Baldassare for pointing out the relationship of our hypotheses to these broader causal categories.

2. Much publicity has surrounded the growth of the multimedia industry, which is concentrated in New York and San Francisco. While multimedia undoubtedly contributes in many different, often intangible ways to the economies of these cities, it cannot be considered a major employment generator: For instance, San Francisco arguably has the largest concentration of multimedia firms in the world, but employment in the industry totals some 3,000 jobs, according to a recent study by the San Francisco Planning Department.

3. For instance, William J. Wilson (1996) points out that "whereas 74 percent of all the white employers who responded to the open-ended questions expressed negative views of the job-related traits of inner-city blacks, 80 percent of the black employers did so as well."

4. Hiring differences occur not only between minority groups, but within: A study in Los Angeles found that dark-skinned black men were 52 percent less likely to be working than light-skinned black men, controlling for education, income, family background, and place of residence (Johnson et al., 1995).

5. Of course, the association of a higher proportion of black employees with informal recruitment mechanisms may simply be due to the existing racial composition of the sector or the racial/ethnic niche because, as Jomills Henry Braddock II and James M. McPartland (1987) have shown, the percentage of blacks in a firm's current work force is a strong predictor of the probability that blacks will apply for work at a firm.

6. St. Clair Drake and Horace R. Cayton (1945) describe how the arrival of tens of thousands of Southern blacks in Chicago increased the percentage of blacks in unskilled and semiskilled jobs relative to those in white-collar occupations; the success of some older residents in breaking through the "job ceiling" to white-collar jobs was not replicated as the new arrivals simply crowded into the old occupational niches, such as domestic service.

7. By commenting on this article, Melvin Webber has suggested that our review implies that competing multicausal theories of complex social phenomena can and should be simultaneously accepted. In one sense, this is a very popular idea in social science, where things are rarely cut and dried. It is far more problematical in the realm of policy, where right (and preferably simple) answers often seem to be the dominant objective.

\section{References}

Abramson, Alan J., Mitchell S. Tobin, and Matthew R. VanderGoot. 1995. "The Changing Geography of Metropolitan Opportunity: The Segregation of the Poor in U.S. Metropolitan Areas, 1970-1990," Housing Policy Debate 6(1):45-72.

Abu-Lughod, Janet. 1994. From Urban Village to East Village: The Battle for New York's Lower East Side. New York: Basil Blackwell.

Altonji, Joseph G., and David Card. 1990. "The Effects of Immigration on the Labor Market Outcomes of Natives," in Immigration, Trade, and the Labor Market, Richard B. Freeman and John M. Abowd, eds. Chicago: University of Chicago Press. 
Auletta, Ken. 1982. The Underclass. New York: Random House.

Bailey, Thomas. 1987. Immigrant and Native Workers: Contrasts and Competition. Boulder, CO: Westview Press.

Baldassare, Mark. 1994. The Los Angeles Riots: Lessons for the Urban Future. Boulder, CO: Westview Press.

Bane, Mary Jo, and David T. Ellwood. 1994. Welfare Realities: From Rhetoric to Reform. Cambridge, MA: Harvard University Press.

Bates, Timothy. 1995. "Why Do Minority Business Development Programs Generate So Little Minority Business Development?” Economic Development Quarterly 9(1):3-14.

—. 1994. "An Analysis of Korean-Immigrant-Owned Small-Business Start-Ups with Comparisons to African-American and Nonminority-Owned Firms," Urban Affairs Quarterly 30(2):227-248.

Becker, Gary. 1975. Human Capital. New York: Columbia University Press, 2d ed. 1957. The Economics of Discrimination. Chicago: University of Chicago Press.

Bell, Daniel. 1973. The Coming of Post-Industrial Society: A Venture in Social Forecasting. New York: Basic Books.

Bellah, Robert, Richard Madsen, William M. Sullivan, Ann Swidler, and Steven M. Tipton. 1985. Habits of the Heart: Individualism and Commitment in American Life. Berkeley: University of California Press.

Berry, Brian. 1985. "Islands of Renewal in Seas of Decay," in The New Urban Reality, Paul Peterson, ed. Washington, DC: The Brookings Institution.

Birch, David. 1987. Job Creation in America. New York: Free Press.

Blakely, Edward J. 1989. Planning Local Economic Development. Newbury Park, CA: Sage Publications.

Bluestone, Barry, and Bennett Harrison. 1982. The Deindustrialization of America. New York: Basic Books.

Boston, T. D., and C.L. Ross. 1996. "Location Preferences of Successful African American-Owned Businesses in Atlanta," Review of Black Political Economy 24 (2-3):337-357.

Bourgois, Philippe. 1995. In Search of Respect: Selling Crack in El Barrio. New York: Cambridge University Press.

Boyd, Robert L. 1990. "Black and Asian Self-Employment in Large Metropolitan Areas: A Comparative Analysis," Social Problems 37(2):258-274.

Braddock, Jomills Henry, II, and James M. McPartland. 1987. "How Minorities Continue To Be Excluded from Equal Employment Opportunities: Research on Labor Market and Institutional Barriers," Journal of Social Issues 43(1):5-39. 
Butler, John S. 1996. "Entrepreneurship and the Advantages of the Inner City: How to Augment the Porter Thesis," Review of Black Political Economy 24(2-3):39-50.

Carnoy, Martin. 1994. Faded Dreams: The Politics and Economics of Race in America. New York: Cambridge University Press.

Case, Anne C., and Lawrence F. Katz. 1990. "The Company You Keep: The Effects of Family and Neighborhood on Disadvantaged Youths." Unpublished paper. Cambridge, MA: National Bureau of Economic Research.

Castells, Manuel. 1996. The Rise of the Network Society. Cambridge, MA: Blackwell. 1989. The Informational City: Information Technology, Economic Restructuring and the Urban-Regional Process. Cambridge, MA: Blackwell.

Castells, Manuel, and Peter Hall. 1994. Technopoles of the World: The Making of TwentyFirst-Century Industrial Complexes. New York: Routledge.

Cohen, Stephen, and John Zysman. 1987. Manufacturing Matters: The Myth of the Post-Industrial Economy. New York: Basic Books.

Coleman, J. 1990. Foundations of Social Theory. Cambridge, MA: Belknap/Harvard University Press.

- 1988. "Social Capital in the Creation of Human Capital," American Journal of Sociology 94(1):95-120.

Corcoran, Mary, Roger Gordon, Deborah Laren, and Gary Solon. 1987. “Intergenerational Transmission of Education, Income, and Earnings.” Unpublished paper. Ann Arbor: University of Michigan.

Crane, Jonathan. 1991. "The Epidemic Theory of Ghettos and Neighborhood Effects on Dropping Out and Teenage Childbearing," American Journal of Sociology 96(5): 1226-1259.

Cross, Harry, Genevieve Kenney, Jane Mell, and Wendy Zimmermann. 1990. Employer Hiring Practices. Washington, DC: Urban Institute Press.

Cutler, David M., and Edward L. Glaeser. 1997. "Are Ghettos Good or Bad?" Quarterly Journal of Economics 112(3):827-872.

Daniels, Peter W. 1975. Office Location. London: Bell.

Danziger, Sheldon H., and Peter Gottschalk. 1985. "The Poverty of Losing Ground," Challenge May/June:32-38.

Datcher, Linda. 1982. "Effects of Community and Family Background on Achievement," Review of Economics and Statistics 64(1):32-41.

De Forest, Robert W., and Lawrence Veiller. 1903. The Tenement House Problem, Including the Report of the New York State Tenement House Commission of 1900. London: Macmillan.

Drake, St. Clair, and Horace R. Cayton. 1945. Black Metropolis: A Study of Negro Life in a Northern City. Chicago: University of Chicago Press. 
Duerr Berrick, Jill. 1995. Faces of Poverty: Portraits of Women and Children on Welfare. New York: Oxford University Press.

Dymski, Gary A. 1996. "Business Strategy and Access to Capital in Inner-City Revitalization," Review of Black Political Economy 24(2-3):51-66.

Edin, Kathryn, and Laura Lein. 1996. Making Ends Meet: How Single Mothers Survive Welfare and Low-Wage Work. New York: Russell Sage Foundation.

Eisinger, Peter K. 1988. The Rise of the Entrepreneurial State: State and Local Economic Development Policy in the United States. Madison: University of Wisconsin Press.

Ellwood, David T. 1989. “The Origins of 'Dependency': Choices, Confidence or Culture?” Focus 12(1):6-13.

England, P., and G. Farkas. 1986. Households, Employment and Gender: A Social, Economic and Demographic View. New York: Aldine.

Fainstein, Norman. 1986. "The Underclass/Mismatch Hypothesis as an Explanation for Black Economic Deprivation," Politics and Society 15(4):403-451.

Freeman, Richard B. 1995. “Are Your Wages Set in Beijing?” Journal of Economic Perspectives 9(3):15-32.

Galster, George C. 1996. "Polarization, Place, and Race," in Race, Poverty, and American Cities, John C. Boger and Judith W. Wegner, eds. Chapel Hill: University of North Carolina Press.

- 1992. "Research on Discrimination in Housing and Mortgage Markets," Housing Policy Debate 3(3):639-684.

1991a. "Black Suburbanization: Has It Changed the Relative Location of Races?" Urban Affairs Quarterly 26(4):621-628.

_. 1991b. "Housing Discrimination and Urban Poverty of African-Americans," Journal of Housing Research 2(1):87-122.

Galster, George C., and W. Mark Keeney. 1988. "Race, Residence, Discrimination, and Economic Opportunity: Modeling the Nexus of Urban Racial Phenomena," Urban Affairs Quarterly 24(1):87-117.

Gans, Herbert. 1995. The War Against the Poor: The Underclass and Antipoverty Policy. New York: Basic Books.

Gibson, Karen J. 1996. "Income, Race, and Space: A Comparative Analysis of the Effects of Poverty Concentration on White and Black Neighborhoods in the Detroit and Pittsburgh Metropolitan Areas." Ph.D. dissertation. Berkeley: University of California.

Gilder, George F. 1981. Wealth and Poverty. New York: Basic Books.

Glasgow, Douglas G. 1980. The Black Underclass: Poverty, Unemployment and Entrapment of Ghetto Youth. San Francisco: Jossey-Bass Publishing.

Glickman, Norman J., M.J. Lahr, and E.K. Wyly. 1996. State of the Nation's Cities. Washington, DC: U.S. Department of Housing and Urban Development. 
Granovetter, Mark. 1973. “The Strength of Weak Ties,” American Journal of Sociology 78 (May):1360-1380.

Granovetter, Mark, and Charles Tilly. 1988. "Inequality and Labor Processes," in Handbook of Sociology, Neil Smelser, ed. Newbury Park, CA: Sage Publications.

Greenstein, R. 1985. "Losing Faith in 'Losing Ground'," New Republic (March 25): $12-17$.

Hanson, Susan, and Geraldine Pratt. 1995. Gender, Work, and Space. New York: Routledge.

Harris, Kathleen. 1993. "Work and Welfare among Single Mothers in Poverty," American Journal of Sociology 99(2):317-352.

Harrison, Bennett. 1994. Lean and Mean: The Changing Landscape of Corporate Power in the Age of Flexibility. New York: Basic Books.

Harrison, Bennett, and Barry Bluestone. 1988. The Great U-Turn: Corporate Restructuring and the Polarizing of America. New York: Basic Books.

Harrison, Bennett, and Amy K. Glasmeier. 1997. "Why Business Alone Won't Redevelop the Inner City: A Friendly Critique of Michael Porter's Approach to Urban Revitalization," Economic Development Quarterly 11(1):28-38.

Hirsch, Arnold R. 1983. Making the Second Ghetto: Race and Housing in Chicago, 1940-1960. New York: Cambridge University Press.

Holzer, Harry. 1995. What Employers Want: Job Prospects for the Less-Educated. New York: Russell Sage Foundation.

1991. "The Spatial Mismatch Hypothesis: What Has the Evidence Shown?" Urban Studies 28(1):105-122.

Hughes, Mark Alan. 1995. “A Mobility Strategy for Improving Opportunity,” Housing Policy Debate 6(1):271-297.

Ihlanfeldt, Keith R. 1991. "The Effect of Job Access on Black and White Youth Employment: A Cross Section Analysis," Urban Studies 28(2):255-265.

Ihlanfeldt, Keith R. and David L. Sjoquist. 1990. "Job Accessibility and Racial Differences in Youth Employment Rates," American Economic Review 80(1):267-276.

. 1989. "The Impact of Job Decentralization on the Economic Welfare of Central City Blacks,” Journal of Urban Economics 26(1):110-130.

Jackson, Kenneth. 1985. Crabgrass Frontier: The Suburbanization of the United States. New York: Oxford University Press.

Jaynes, Gerald D. 1990. “The Labor Market Status of Black Americans: 1939-1985," Journal of Economic Perspectives 4(4):9-24.

Jencks, Christopher, and Susan Mayer. 1990a. "Residential Segregation, Job Proximity, and Black Job Opportunities," in Inner-City Poverty in the United States, Laurence E. Lynn, Jr., and Michael G.H. McGeary, eds. Washington, DC: National Academy Press. 
1990b. "The Social Consequences of Growing Up in a Poor Neighborhood," in Inner-City Poverty in the United States, Laurence E. Lynn, Jr., and Michael G.H. McGeary, eds. Washington, DC: National Academy Press.

Jencks, Christopher, and Paul Peterson, eds. 1991. The Urban Underclass. Washington, DC: The Brookings Institution.

Johnson, James, Elisa Bienenstock, and Jennifer Stoloff. 1995. "An Empirical Test of the Cultural Capital Hypothesis," Review of Black Political Economy 23(Spring):7-27.

Kain, John F. 1992. "The Spatial Mismatch Hypothesis: Three Decades Later," Housing Policy Debate 3(2):371-469.

. 1968. "Housing Segregation, Negro Employment, and Metropolitan Decentralization," Quarterly Journal of Economics 82(2):175-197.

Kasarda, John. 1993. "Inner-City Concentrated Poverty and Neighborhood Distress: 1970 to 1990," Housing Policy Debate 4(3):253-302.

1990. "City Jobs and Residents on a Collision Course: The Urban Underclass Dilemma,” Economic Development Quarterly 4(4):313-319.

1989. "Urban Industrial Transition and the Underclass," Annals of the American Academy of Political and Social Science 501:26-47.

1985. "Urban Change and Minority Opportunities," in The New Urban Reality, Paul Peterson, ed. Washington, DC: The Brookings Institution.

Kasarda, John, and Ting, K. 1996. "Joblessness and Poverty in America's Central Cities: Causes and Policy Prescriptions," Housing Policy Debate 7(2):387-419.

Kasinitz, Philip and Jan Rosenberg. 1993. "Why Enterprise Zones Will Not Work,” City Journal (Autumn):63-69.

Kelly, M. Patricia Fernandez. 1994. “Towanda's Triumph: Social and Cultural Capital in the Transition to Adulthood in the Urban Ghetto," International Journal of Urban and Regional Research 18(1)(March):88-111.

Kirschenman, Joleen, Philip Moss, and Chris Tilly. 1995. Employer Screening Methods and Racial Exclusion: Evidence from New In-Depth Interviews with Employers. New York: Russell Sage Foundation.

Lemann, Nicholas. 1991. The Promised Land: The Great Migration and How It Changed America. New York: Alfred A. Knopf.

Levy, Frank, and Richard Murnane. 1992. "U.S. Earnings Levels and Earnings Inequality: A Review of Recent Trends and Proposed Explanations," Journal of Economic Literature 30(3):1333-1381.

Lewis, Oscar. 1959. "The Culture of Poverty," reprinted in On Understanding Poverty: Perspectives from the Social Sciences, Daniel P. Moynihan, ed. New York: Basic Books, 1968.

Lieberson, Stanley. 1978. "A Reconsideration of the Income Differences Found between Migrants and Northern-Born Blacks,” American Journal of Sociology 83(4):940-966. 
Liebow, E. 1967. Tally's Corner: A Study of Negro Streetcorner Men. Boston: Little, Brown.

Massey, Douglas, and Nancy Denton. 1993. American Apartheid: Segregation and the Making of the Underclass. Cambridge, MA: Harvard University Press.

Massey, Douglas, Andrew Gross, and Mitchell Eggers. 1991. "Segregation, the Concentration of Poverty, and the Life Chances of Individuals," Social Science Research 20(4):397-420.

Massey, Douglas S., Andrew Gross, and Kumiko Shibuya. 1994. "Migration, Segregation, and the Concentration of Poverty," American Sociological Review 59(June): 1153-1189.

Mead, Lawrence. 1986. Beyond Entitlement: The Social Obligations of Citizenship. New York: Free Press.

Meyerson, Martin, and Edward C. Banfield. 1955. Politics, Planning and the Public Interest: The Case of Public Housing in Chicago. New York: Free Press.

Mier, Robert, and Robert Giloth. 1985. "Hispanic Employment Opportunities: A Case of Internal Labor Markets and Weak-Tied Social Networks," Social Science Quarterly 66(2):296-309.

Mincy, Ronald B. 1994. "The Underclass: Concept, Controversy, and Evidence," in Confronting Poverty: Prescriptions for Change, Sheldon H. Danziger, Gary D. Sandefur, and Daniel H. Weinberg, eds. Cambridge, MA: Harvard University Press.

Mollenkopf, John M., and Manuel Castells, eds. 1991. Dual City: Restructuring New York. New York: Russell Sage Foundation.

Moss, Philip, and Chris Tilly. 1995. Raised Hurdles for Black Men: Evidence from Interviews with Employers. New York: Russell Sage Foundation.

. 1991. Why Black Men Are Doing Worse in the Labor Market: A Review of Supply-Side and Demand-Side Explanations. New York: Social Science Research Council.

Munnell, Alicia H., Lynn E. Browne, James McEneaney, and Geoffrey Tootell. 1992. Mortgage Lending in Boston: Interpreting HMDA Data. Boston: Federal Reserve Bank.

Murray, Charles. 1984. Losing Ground: American Social Policy 1950-1980. New York: Basic Books.

Neckerman, Kathryn M., and Joleen Kirschenman. 1991. "Hiring Strategies, Racial Bias, and Inner-City Workers." Social Problems 38(November):433-447.

Nisbet, Robert. 1976. The Quest for Community. New York: Oxford University Press.

Noyelle, Thierry J. 1987. Beyond Industrial Dualism: Market and Job Segmentation in the New Economy. Boulder, CO: Westview Press.

Noyelle, Thierry J., and Thomas M. Stanback. 1983. The Economic Transformation of American Cities. Totowa, NJ: Rowman \& Allenheld. 
O’Neill, June. 1990. “The Role of Human Capital in Earnings Differences between Black and White Men," Journal of Economic Perspectives 4(4):25-46.

Ong, Paul, and Abel Valenzuela, Jr. 1996. "The Labor Market: Immigrant Effects and Racial Disparities," in Ethnic Los Angeles, Roger Waldinger and Mehdi Bozorgmehr, eds. New York: Russell Sage Foundation.

Park, Robert. 1969. "The City: Suggestions for the Investigation of Human Behavior in the Urban Environment," in Classical Essays on the Culture of Cities, Richard Sennett, ed. Englewood Cliffs, NJ: Prentice-Hall.

Peterson, George E., and Wayne Vroman, eds. 1992. Urban Labor Markets and Job Opportunity. Washington, DC: Urban Institute Press.

Peterson, Ruth, and Lauren Krivo. 1993. "Racial Segregation and Black Urban Homicide," Social Forces 71:1001-1026.

Piore, Michael J., and Charles F. Sabel. 1984. The Second Industrial Divide: Possibilities for Prosperity. New York: Basic Books.

Porter, Michael E. 1995. "The Competitive Advantage of the Inner City," Harvard Business Review (May/June):55-71.

Portes, Alejandro, and J. Sensenbrenner. 1993. "Embeddedness and Immigration: Notes on the Social Determinants of Economic Action," American Journal of Sociology 98(6):1320-1350.

Portes, Alejandro, and Min Zhou. 1993. "The New Second Generation: Segmented Assimilation and Its Variants," Annals of the American Academy of Political and Social Science 530:74-96.

Portney, K.E., and J.M. Berry. 1997. "Mobilizing Minority Communities: Social Capital and Participation in Urban Neighborhoods," American Behavioral Scientist 40(5): 632-644.

Putnam, Robert. 1993. Making Democracy Work: Civic Traditions in Modern Italy. Princeton, NJ: Princeton University Press.

Rainwater, Lee. 1970. Behind Ghetto Walls: Black Families in a Federal Slum. Chicago: Aldine.

Reich, Robert. 1992. The Work of Nations. New York: Vintage Books.

Reskin, Barbara, and Heidi Hartmann. 1986. Women's Work, Men's Work: Sex Segregation on the Job. Washington, DC: National Academy Press.

Ricketts, Erol R., and Isabel V. Sawhill. 1988. "Defining and Measuring the Underclass," Journal of Policy Analysis and Measurement 7(2):316-322.

Rosenbaum, James. 1995. "Changing the Geography of Opportunity by Expanding Residential Choice: Lessons from the Gautreaux Program," Housing Policy Debate 6(1):231-269. 
Sanders, J.M., and V. Nee. 1996. "Immigrant Self-Employment: The Family as Social

Capital and the Value of Human Capital," American Sociological Review 61(2):231-249.

Sassen, Saskia. 1991. The Global City: New York, London, Tokyo. Princeton, NJ:

Princeton University Press.

Sassen-Koob, Saskia. 1984. "The New Labor Demand in Global Cities," in Cities in Transformation: Class, Capital and the State, Michael P. Smith, ed. Beverly Hills, CA: Sage Publications.

Sawhill, Isabel V. 1988. "Poverty in the U.S.: Why Is It So Persistent?" Journal of Economic Literature 27(3):1073-1119.

Saxenian, AnnaLee. 1994. Regional Advantage: Culture and Competition in Silicon Valley and Route 128. Cambridge, MA: Harvard University Press.

Schneider, Mark, and Thomas Phelan. 1990. "Blacks and Jobs: Never the Twain Shall Meet?” Urban Affairs Quarterly 26(2):299-312.

Scott, Allen. 1993. Technopolis: High-Technology Industry and Regional Development in Southern California. Berkeley: University of California Press.

Shulman, S. 1990. "The Causes of Black Poverty: Evidence and Interpretation," Journal of Economic Issues 24(4):995-1016.

Smith, James P., and Finis R. Welch. 1989. "Black Economic Progress after Myrdal," Journal of Economic Literature 27(2):519-564.

Smith, Neil. 1996. The New Urban Frontier: Gentrification and the Revanchist City. New York: Routledge.

- 1982. "Gentrification and Urban Development," Economic Geography 58(1):139-155.

Stanback, Thomas M., Jr., Peter J. Bearse, Thierry J. Noyelle, and Robert Karasek. 1981. Services: The New Economy. Totowa, NJ: Allanheld, Osmun.

Taylor, Brian D., and Paul M. Ong. 1995. "Spatial Mismatch or Automobile Mismatch: An Examination of Race, Residence and Commuting in U.S. Metropolitan Areas," Urban Studies 32(9):1453-1473.

Teitz, Michael B. 1994. "Changes in Economic Development Theory and Practice," International Regional Science Review 16(1-2):101-106.

Thomas, June Manning. 1996. "Rebuilding Inner Cities: Basic Principles," Review of Black Political Economy 24(2-3):67-74.

Turner, Margery. 1992. "Discrimination in Urban Housing Markets: Lessons from Fair Housing Audits," Housing Policy Debate 3(1):185-216.

Turner, Margery, Michael Fix, and Raymond Struyk. 1991. Opportunities Denied, Opportunities Diminished: Discrimination in Hiring. Washington, DC: Urban Institute Press. 
Turner, Margery, Raymond Struyk, and John Yinger. 1991. Housing Discrimination Study Synthesis. Washington, DC: U.S. Department of Housing and Urban Development, Office of Policy Development and Research.

Turner, Susan. 1997. "Barriers to a Better Break: Employer Discrimination and Spatial Mismatch in Metropolitan Detroit," Journal of Urban Affairs 19(2):123-141.

Van Haitsma, Martha. 1989. "A Contextual Definition of the Underclass," Focus 12(1)(Spring/Summer):27-31.

Vernon, Raymond. 1960. Metropolis 1985: An Interpretation of the Findings of the New York Metropolitan Region Study. Cambridge, MA: Harvard University Press.

Wacquant, Loic. 1997. "Three Pernicious Premises in the Study of the American Ghetto," International Journal of Urban and Regional Research 21(July):341-353.

Waldinger, Roger. 1996. Still the Promised City?: African-Americans and New Immigrants in Postindustrial New York. Cambridge, MA: Harvard University Press.

1994. "Black/Immigrant Competition Reassessed: New Evidence from Los Angeles." Unpublished paper. Los Angeles: University of California at Los Angeles, Department of Sociology.

1986. Through the Eye of the Needle: Immigrants and Enterprise in New York's Garment Trade. New York: New York University Press.

Waller, Maureen. 1996. "Redefining Fatherhood: Paternal Involvement, Masculinity and Responsibility in the 'Other America'." Ph.D. dissertation. Princeton, NJ: Princeton University.

Webber, Michael John, and David L. Rigby. 1996. The Golden Age Illusion: Rethinking Postwar Capitalism. New York: Guilford Press.

Weiss, Marc A. 1980. "The Origins and Legacy of Urban Renewal," in Urban and Regional Planning in an Age of Austerity, Pierre Clavel and John Forester, eds. New York: Pergamon.

West, Cornel. 1993. Race Matters. New York: Vintage Books.

Wilson, G. 1996. "Toward a Revised Framework for Examining Beliefs about the Causes of Poverty," Sociological Quarterly 37(3):413-428.

Wilson, William Julius. 1996. When Work Disappears: The World of the New Urban Poor. Princeton, NJ: Princeton University Press.

1987. The Truly Disadvantaged: The Inner City, the Underclass, and Public Policy. Chicago: University of Chicago Press.

Wilson, William J., and Robert Aponte. 1985. "Urban Poverty,” Annual Review of Sociology 11:231-258.

Wirth, Louis. 1969. "Urbanism as a Way of Life," in Classical Essays on the Culture of Cities, Richard Sennett, ed. Englewood Cliffs, NJ: Prentice-Hall. 
Wood, Adrian. 1995. "How Trade Hurt Unskilled Workers," Journal of Economic Perspectives 9(3):57-80.

Zax, Jeffrey S., and John F. Kain. 1992. "Moving to the Suburbs: Do Relocating Companies Leave Their Black Employees Behind?" Harvard Institute of Economic Research Discussion Paper. Cambridge, MA: Harvard University. 